\title{
Determination of optimum processing conditions for extruded rice cake using response surface methodology
}

\author{
Hyung Joo Kim ${ }^{1}$, Won Byong Yoon ${ }^{1,2 *}$ \\ ${ }^{1}$ Department of Food Science and Biotechnology, Kangwon National University, Chuncheon 24341, Korea \\ ${ }^{2}$ Elderly-Friendly Food Research Center, Agriculture and Life Science Research Institute, \\ Kangwon National University, Chuncheon 24341, Korea
}

\section{반응표면분석을 이용한 압출 떡 제조 공정의 최적화

\author{
김형주 ${ }^{1} \cdot$ 윤원병 ${ }^{1,2 *}$ \\ 1강원대학교 식품생명공학과, ${ }^{2}$ 농업생명과학연구원 고령친화생물소재연구센터
}

\begin{abstract}
The optimum processing conditions for extruded rice cakes were determined using response surface methodology. Lab-scale processing equipment was developed and tested under various processing conditions. This study specifically attempted to determine the ideal condtions for producing rice cakes by applying different extrusion conditions, namely, different moisture contents, rice flour particle size, steaming time, and number of extrusions. The quality properties of the rice cakes were evaluated by measuring their texture properties and color values. The response surface method was applied to design the experiment and to develop model equations based on the experimental data. The target quality values were determined by measuring the quality parameters of commercial rice cakes. The samples were prepared with different ratios of water content in the label and with different types of rice flour (well-milled and dried rice flour) to extend the feasibility. For samples prepared with dried rice flour using a batch:water content of 1:0.4, the optimum steaming time and number of extrusions were determined to be approximately 116 min and one, respectively, whereas they were $115 \mathrm{~min}$ and one, respectively, for the sample with the ratio 1:0.5. The optimum texture properties for the sample produced with flour prepared at the lab scale were achieved using 111 min of steaming and three extrusion cycles. Thus, the optimum processing conditions for producing extruded rice cakes using lab-scale production units were determined.
\end{abstract}

Key words : extrusion, extruded rice cake, lab-scale production, response surface method, optimization

서 론

최근 1 인 가구수의 증가, 외식 빈도 증가, 식습관의 서구화 등의 이유로 국내 1 인당 연간 쌀 소비량은 2015 년에 $62.9 \mathrm{~kg}$, 2016년에 $61.9 \mathrm{~kg}$, 2017년에 $61.8 \mathrm{~kg}, 2018$ 년 $61 \mathrm{~kg}, 2019$ 년 에 $59.2 \mathrm{~kg}$ 으로 매해 감소하고 있는 추세이다(KOSIS, 2019). 정부는 잉여 쌀의 효율적인 활용을 위하여 다양한 쌀 가공품
의 개발에 많은 노력을 기울이고 있다. 그 중에서도 떡은 음 료, 주류 혹은 전통주와 함께 대표적인 쌀 가공품으로써 쌀가 루, 찹쌀가루, 감자가루 또는 전분이나 기타 곡물분말 등을 주원료로 하여 이에 식염, 당류, 곡류, 두류, 채소류, 과일류 또는 주류 등을 가하여 반죽하여 증자 및 압출을 통하여 제조 한 것(MFDS, 2018)으로 변화된 소비자의 식습관에 따라 다 양한 떡 제품의 개발과 간식과 주식으로 이용도가 증가하고

*Corresponding author. E-mail : wbyoon@kangwon.ac.kr, Phone : +82-33-250-6459, Fax : +82-33-259-5565

Received 16 June 2020; Revised 07 July 2020; Accepted 17 July 2020.

Copyright (c) The Korean Society of Food Preservation.

This is an Open Access article distributed under the terms of the Creative Commons Attribution Non-Commercial License (http://creativecommons.org/licenses/by-nc/4.0) which permits unrestricted non-commercial use, distribution, and reproduction in any medium, provided the original work is properly cited. 
있다(Kum, 2008; Lee, 1999). 떡의 수요는 2015년에 977억 원, 2016년에 1,043 억 원, 2017 년에 1,122 억 원, 그리고, 2018년에 1,281 억 원이었으며, 이들 떡류의 주요 제품은 2018 년 기준 떡볶이 떡(69.3\%), 떡국 떡(24.4\%) 및 기타 떡 류(6.3\%)로 압출 떡 종류인 떡볶이 떡과 떡국 떡이 떡가공제 품의 주요 제품임이 확인되었다(aTFIS, 2019).

압출 떡의 수요증가에 따른 유통기한의 연장, 품질 개선, 영양성분 강화 등의 다양한 연구들이 진행되고 있다. 산 침지 및 살균 혹은 자몽종자 추출물 첨가를 통한 떡의 유통기한 연장을 위한 연구(Jung 등, 2018; Kang 등, 2013), 인삼 혹은 파래 분말의 첨가를 통한 기능성 향상(Jung 등, 2019; Lee 등, 2011), 대두의 첨가를 통한 떡의 노화 억제(Kang 등, 2012a) 등의 다양한 연구가 진행되고 있다. 이와 같은 연구를 압출 떡에 적용하기 위해서는 실험실적 규모(lab-scale) 또는 파일롯 규모(pilot-scale)의 실험이 절대적으로 필요하나, 압 출 떡 제조 시에 필수적으로 동반하는 증자공정과 압출공정 의 조건을 실험실적 조건에서 재현성 있게 도출하는 것은 장 비의 한계점으로 매우 어려우며, 현재 정립이 되어 있지 않은 상황이다. 일반적으로 연구 진행을 위해서는 방앗간이나 떡 공장에 시제품의 제조를 의뢰하여 실험을 진행하고 있으나, 이는 대량 생산(industry-scale)을 주 목적으로 하는 공장의 특성에 부합되지 않아 시제품의 제조에 많은 한계점이 존재하 고 있으며, 또한 제조 후 즉각적인 실험의 진행이 어려우므로 이송 중에 발생하는 교차오염 및 노화 등의 물리적 성질의 변 화로 인해 실험결과의 재현성을 현저하게 저하시키게 된다.

압출 떡을 제조할 경우, 동일한 배합비 상태에서 적용되는 증자시간과 압출횟수가 압출 떡의 주요한 품질인자인 조직감 에 영향을 주는 것으로 보고되었다(Kang 등, 2012b; Yu와 Han, 2004). 압출 떡의 압출 조건에 따른 품질변화에 대한 연구는 가수량을 달리한 떡볶이용 가래떡의 품질특성 평가 (Kang 등, 2012b), 쌀의 수침시간 및 증자시간에 따른 가래떡 의 품질 특성 비교(Yu와 Han, 2004), 압출성형 횟수가 떡국 떡의 품질 특성에 미치는 영향(Bae 등, 2016)이 있으나, 위와 같은 선행연구에서는 증자시간과 압출횟수의 복합공정이 압 출 떡의 물리적 특성에 미치는 연구는 보고된 바가 없다.

쌀가루(미분) 입자의 크기도 동일한 배합비일 경우, 압출 떡의 조직감에 영향을 주는 인자로 알려져 있다(Park 등, 2018). 현재 진행되고 있는 연구에 사용되는 쌀가루는 실험 실에서 수침 후 분쇄하여 자체적으로 제작한 미분을 사용하 는 경우와 시중에 유통되는 건조 미분을 사용하는 경우가 있 다. 이와 같이 준비된 시료 간의 입자도의 차이(Lee 등, 2015) 와 수분함량 차이(Yu와 Han, 2004)에 따른 품질특성에 미치 는 영향에 대한 연구보고가 있으나, 상용화된 미분과 실험실 에서 제조한 미분을 압출 떡 제조의 핵심적인 공정인 증자시
간과 압출횟수에 따라 떡의 품질에 미치는 영향에 대한 연구 는 보고된 바가 없다.

최적공정조건은 수학적인 최적화 기법을 사용하여 도출될 수 있다. 반응표면분석법은 독립변수들과 종속변수간의 상관 관계를 분석하여 최적 조건을 찾아내는 실험계획법으로 변수 간의 함수관계를 도출하여 공정에서의 최적 조건을 도출하는 분석법이다(Lee, 2008). 반응표면분석법은 증류, 건조, 발효, 추출 및 살균과 같은 식품 제조 중의 여러 단위 공정의 최적 화에 사용되고 있으며, 이와 같은 수학적인 모델과 분석을 통 한 공정의 개발과 최적공정 도출은 인력과 시간 및 연구에 사용되는 비용의 효율화를 기할 수 있다(Park 등, 2011). 이 같은 장점으로 새로운 공정의 개발 혹은 최적공정 조건 도출 에 적절한 실험계획법 및 수학적 모형의 도입과 최적화 이론 의 적용이 지속적으로 이루어지고 있는 추세이다(Park 등, 2011; Sim, 2011).

본 연구의 목적은 시판 떡볶이 떡 제품들과 유사한 물리적 특성을 가지는 실험실 규모(lab-scale)의 압출 떡 생산공정을 개발하는 것이다. 개발된 공정의 최적공정 조건을 도출하기 위하여 반응표면분석법(RSM)과 수학적인 모형을 적용하여 증자시간과 압출횟수가 압출 떡의 조직감에 미치는 영향을 확인하고 해석하는 것이다.

\section{재료 및 방법}

\section{실험재료}

연구에 사용된 쌀 시료는 두 종류로서 멥쌀로 제조된 상용 화된 건식미분(Nongshim Flour Mills Co., Asan, Korea)과 쌀(Naesu Nonghyup, Cheongwon, Korea)을 실험실에서 수 침 후 분쇄하여 만든 쌀가루를 사용하여 압출 떡을 제조하였 다. 건식미분의 경우, $100 \%$ 국내산 가공용 쌀로서 혼합된 종 을 사용하여 농심미분(Nongshim Flour Mills Co.)에서 떡 제 조용 건식미분으로 제조한 것을 사용하였다. 실험실에서 수 침 후 분쇄하여 사용한 쌀은 경기미로 해당 품종의 아밀로스 함량은 $19.7 \%$ 이상인 것으로 Kim 등(2006)의 방법에 의하여 확인하였다. 첨가제로는 소금(Chungjungone, Seoul, Korea) 과 유화유지(Nawon Co., Eumseong, Korea)를 사용하였으 며, 소금은 인근 시장에서 구매하였다. 쌀, 소금, 유화유지는 모두 상온에서 보관하며 사용하였으며, 건식미분의 경우 $4^{\circ} \mathrm{C}$ 의 냉장실에 보관하며 사용하였다. 압출 떡은 상온에서 제조 하였으며, 제조 후 상온에서 보관하며 제조 후 60 분 이내에 품질특성을 측정하였다.

\section{쌀 수침 시 수분 평형 도달 시간 측정}

쌀의 수침은 $25 \pm 2^{\circ} \mathrm{C}$ 의 상온 조건에서 쌀 $300 \mathrm{~g}$ 을 $1 \mathrm{~L}$ 비이 
커에 넣은 후, 증류수 $600 \mathrm{~mL}$ 를 첨가하여 침지를 진행하였 다. 수침된 쌀이 수분 평형을 이루는 시간 및 당시의 함량을 확인하기 위해 15 분, 30 분, 1 시간, 2 시간, 4 시간, 8 시간, 16 시 간의 침지 시간을 적용하였으며, 침지 종료 후 10 분간 0.25 $\mathrm{mm}$ 구경의 분리용 체(Chunggye, Seoul, Korea) 위에 올려서 표면의 수분을 제거한 후 쌀의 수분함량을 측정하였다.

\section{분쇄 및 입자도 측정}

침지 쌀의 분쇄는 $25 \pm 2^{\circ} \mathrm{C}$ 의 상온 조건에서 $650 \mathrm{~W}$ 건조 분쇄기(HMF-3250S, Hanil Electric, Seoul, Korea)를 사용하 여 30 초간 5 회 반복 진행하였으며, 균일한 분쇄를 위하여 쌀 을 30 초마다 섞어주며 분쇄를 진행하였다. 분쇄된 쌀의 입자 크기 분포를 확인하기 위해 분쇄된 쌀 $200 \mathrm{~g}$ 을 mesh 크기가 다른 5 개의 체 $(1.18,1.00,0.60,0.43,0.25 \mathrm{~mm})$ 의 가장 위 에 배치한 후, 체가름 시험기(CG-211-8, Chunggye)에 장 착하여 5 분 동안 체가름을 진행하였다. 서로 다른 mesh 크기를 가지는 체 위에 존재하는 미분들의 질량을 총 미 분질량으로 나누어 수침 후 쌀 분쇄 시 발생하는 미분의 수율을 입차 크기 별로 나타내었다(Djantou 등, 2007).

\section{압출 떡의 제조}

본 연구에서 사용한 배합은 미분 $750 \mathrm{~g}$ 에 소금 $7.5 \mathrm{~g}$, 유화 유지 $3.75 \mathrm{~g}$ 을 첨가한 후, 총 고형분의 각각 $40 \%, 50 \%$ 에 해 당하는 증류수를 사용하여 압출 떡을 제조하였다. 쌀가루 및 첨가물을 첨가한 고형분 대비 $40 \%$ 와 $50 \%$ 함량의 수분을 일정 량씩 첨가하며 교반기(DSM-12P, Daeyung Bakery Machinery Co., Seoul, Korea)를 15 분간 작동시켜 교반을 진행하였다. 이후 $120^{\circ} \mathrm{C}$ 에서 찜기(KRRSB10W, Koresta, Seoul, Korea)를 이용한 증자 과정을 각각 20 분, 40 분, 80 분, 120 분 적용한 후, 실험실 규모의 압출기(Shandong Luerya Machinery Co., Ltd., Shandong, China)를 통해 떡을 압출성형 하였다. 압출과정은 각각 1 회, 2 회, 3 회 진행하였으며, 압출이 완전히 종료된 후 냉수 $\left(24^{\circ} \mathrm{C}\right)$ 에 5 분간 냉각을 진행하였다. 본 연구에서는 해당 시료를 떡볶이용 압출 떡이라고 칭하였다.

수침한 쌀을 분쇄하여 만든 미분을 사용하여 압출 떡을 제 조 시에는 수침된 쌀이 포함하고 있는 수분의 양을 고려해야 하므로 수분 평형을 이룬 수침 쌀의 수분 함량 $(30 \%)$ 과 수침 전 쌀의 수분 함량 $(10 \%)$ 을 고려하여, 미분 $750 \mathrm{~g}$ 에 소금 7.5 $\mathrm{g}$, 유화유지 $3.75 \mathrm{~g}$ 을 첨가한 후 교반 과정 중 증류수 150 $\mathrm{g}$ 을 첨가한 배합비를 사용하였으며, 이외의 압출 공정은 위 와 동일하게 진행하였다. 제조된 압출 떡과 시중 떡볶이용 떡 의 수분함량은 $105^{\circ} \mathrm{C}$ 로 설정된 dry oven(NB-901M, NBIOTEK, Bucheon, Korea)에서 상압 가열 건조법(AOAC, 1996)으로 3반복 측정하여 그 평균값을 결과를 나타내었다.

\section{조직감 측정}

압출 떡과 시중 떡볶이용 떡의 물리적 특성은 texture analyzer(TA.XT plus 100C, Stable Micro Systems Ltd., Godalming, UK)를 이용하여 TPA(texture profile analysis) test mode로 값을 측정하였다(Kang 등, 2012a). 조직감 측정 을 위해 프로브는 $25.4 \mathrm{~mm}$ 의 지름을 가지는 원기둥 형태의 프로브를 사용하였으며, TA.XT의 측정은 pre-test speed 1 $\mathrm{mm} / \mathrm{sec}$, test speed $0.5 \mathrm{~mm} / \mathrm{sec}$, post-test speed $5 \mathrm{~mm} / \mathrm{sec}$ 와 같은 환경에서 진행하였다. 변형률(deformation)은 1 차 변형 과 2 차 변형 모두 $50 \%$ 로 설정하여 측정을 진행하였다.

압출 떡과 시중 떡볶이용 떡은 동일한 크기 $(1.0 \times 1.0 \mathrm{~cm})$ 로 잘라 경도(hardness), 부착성(adhesiveness), 응집성(cohesiveness), 씹힘성(chewiness), 점착성(gumminess)을 10 회 반복 측정하여 평균값으로 나타내었다(Jo와 Yoon, 2016). 경도는 1 회차 수직변형 시에 도달하는 최고 힘으로 수직변형과정에 나타나는 힘-거리 곡선의 최고점(peak)의 값을 취하였으며, 부착성(adhesiveness)은 1 회차와 2 회차 수직변형 시에 나타 나는 힘-거리 곡선이 만든 하단부 면적으로 첫 번째 수직변형 이후 프로브와 샘플이 떨어지는데 필요한 힘을 나타내고자 하였다. 응집성(cohesiveness)은 1회차 수직변형과 2회차 수 직변형 시에 발생하는 상단부의 면적의 비로 설정하였으며, 물체가 기존의 형태를 유지하려는 힘을 나타내고자 사용하였 다. 점착성(gumminess)과 씹힘성(chewiness)은 각각 반고체 (semi-solid)와 고체(solid)의 시료를 삼킬 수 있는 정도의 특 성을 나타내는 인자로서 떡의 삼킴성에 대한 특징을 나타내 고자 측정하였으며, 점착성은 경도와 응집성의 곱으로 계산 하였으며, 씹힘성은 점착성과 1 회차 수직변형 시에 발생한 거리와 2회차 수직변형 시에 발생한 거리 비의 곱으로 계산 하였다(Chen 등, 1979).

\section{색도 및 색차 측정}

떡 샘플의 색도는 색차계(Minolta CR-410, Konica Minolta Co., Tokyo, Japan)를 사용하여 10 회 반복 측정하여 평균값 을 사용하였다. L*(lightness), a*(redness), b*(yellowness), $\Delta \mathrm{E}$ (색차지수) 값으로 나타내었다. a값의 증가는 적색을, 감소는 녹색을 나타내며, $\mathrm{b}$ 값의 증가는 황색을, 감소는 청색 의 강도를 의미한다(Lee 등, 2016). 전반적인 색차 $(\Delta \mathrm{E})$ 는 아 래와 같은 식을 통하여 산출하였다.

$$
\Delta E=\sqrt{\left(\Delta L^{*}\right)^{2}+\left(\Delta a^{*}\right)^{2}+\left(\Delta b^{*}\right)^{2}}
$$

\section{반응표면분석}

반응 표면 분석 방법(RSM) 중 중심합성계획법을 이용하 여 실험을 설계 후 진행하였다(Yoon 등 2017). 반응표면분석 
은 Minitab(Version 19, Minitab Inc., State College, PA, $\mathrm{USA})$ 을 이용하였으며, 독립 변수로는 증자시간 $\left(X_{1}\right)$ 과 압출 횟수 $\left(X_{2}\right)$ 를, 종속 변수는 조직감 측정 결과 값들 $\left(Y_{\mathrm{i}}\right)$ 로 설정하 여 진행하였다. 독립변수인 증자시간 및 압출횟수를 실험 범 위에 따라 부호화 및 부호화가 진행되지 않은 실제 실험값을 Table 1에 나타내었다. 이 때 사용된 독립변수의 범위는 예비 실험의 결과를 토대로 설정하였으며, 예비 실험에서 얻은 데 이터의 경우 본 논문의 결과에 반영하지 않았다. 본 연구는 4 개의 꼭지점, 4 개의 축점, 2 개의 중앙점으로 실험을 설계하 였으며, 설계된 10 개의 실험군들은 통계적인 오차를 최소화 하기 위해 임의적인 순서로 진행되었다(Table 2).

\section{모델 방정식 도출 및 최적화}

서로 다른 고형분:수분 함량을 가지는 떡볶이 압출 떡의 조직감 측정 결과를 Minitab(Version 19, Minitab Inc., State College, PA, USA)을 이용하여 증자시간 $\left(X_{1}\right)$ 과 압출횟수

Table 1. Experimental range and values of independent variables in the central composite design for the rice cake processing

\begin{tabular}{lcccc}
\hline & & \multicolumn{4}{c}{ Range and levels } \\
\cline { 3 - 5 } Independent variables & Symbol & -1 & 0 & +1 \\
\hline Steaming time (min) & $X_{1}$ & 40 & 80 & 120 \\
Number of extrusion & $X_{2}$ & 1 & 2 & 3 \\
\hline
\end{tabular}

Table 2. Experimental conditions for the central composite design for the optimization of making extruded rice cake

\begin{tabular}{|c|c|c|c|c|}
\hline \multirow{3}{*}{ Run } & \multicolumn{4}{|c|}{ Experimental factor } \\
\hline & \multicolumn{2}{|c|}{ Coded values } & \multicolumn{2}{|c|}{ Actual values } \\
\hline & $X_{1}$ & $X_{2}$ & $\begin{array}{c}\text { Steaming } \\
\text { time (min) }\end{array}$ & $\begin{array}{l}\text { Number of } \\
\text { extrusion }\end{array}$ \\
\hline 1 & -1 & 1 & 40 & 3 \\
\hline 2 & 0 & 0 & 80 & 2 \\
\hline 3 & 0 & 1 & 80 & 3 \\
\hline 4 & 1 & -1 & 120 & 1 \\
\hline 5 & 0 & 0 & 80 & 2 \\
\hline 6 & 1 & 0 & 120 & 2 \\
\hline 7 & -1 & 0 & 40 & 2 \\
\hline 8 & 1 & 1 & 120 & 3 \\
\hline 9 & -1 & -1 & 40 & 1 \\
\hline 10 & 0 & -1 & 80 & 1 \\
\hline
\end{tabular}

$\left(X_{2}\right)$ 에 의한 조직감 값 $(Y)$ 을 방정식으로 도출하였다. 각 인자의 변화가 떡의 조직감에 미치는 영향을 조사하기 위 하여 교호작용을 포함한 이차다항회귀곡선식을 이용하였 으며, 형태는 다음과 같다.

$$
Y=A_{0}+A_{1} X_{1}+A_{2} X_{2}+A_{3} X_{1}^{2}+A_{4} X_{2}^{2}+A_{5} X_{1} X_{2}
$$

도출한 이차다항식 중 $\mathrm{R}^{2}$ 값이 0.7 이상이며, $\mathrm{p}$-value가 0.05 이하인 항목들에 대하여 Minitab의 response optimizer 를 이용하여 유의미한 항들만을 도출하여 최적화 및 종합 만 족도를 평가하였으며(Yoon 등 2017), 최적화 시에 목표값은 시중 떡볶이 떡의 조직감 인자로 설정하였다. 본 연구에서 사 용한 종합 만족도는 목표값으로 설정한 종속 변수값이 독립 변수의 조합으로 만족되는 정도를 수치화하여 나타내는 것으 로 만족도의 범위는 0 과 1 의 사이이며, 최소치인 0 은 하나 혹은 그 이상의 인자가 허용 한계치를 벗어났음을 의미하며, 최대치는 1은 가장 이상적인 상태를 나타낸다(Jung과 Lee, 2012).

\section{관능평가}

관능검사는 강원대학교 식품생명공학과 대학원생 15 명을 대상으로 충분한 지식과 용어, 평가기준 등을 숙지시킨 후 동 일한 떡볶이 떡 시료에 대한 관능검사를 3 회 실시하여 차이 식별 능력이 우수한 10 명의 학생을 선별하여 실험을 진행하 였다(Heo 등, 2004). 관능검사는 오전 10-11시 사이에 칸막 이가 있는 관능검사실에서 이루어졌으며, 샘플은 입자크기 및 압출 조건이 다르게 적용된 $1 \mathrm{~cm}$ 직경의 떡볶이 압출 떡 을 $1 \mathrm{~cm}$ 길이로 잘라 준비하였다. 샘플은 각각 1 회용 접시에 담아 동시에 제공되었으며, 한 개의 샘플을 평가한 후에는 반 드시 생수로 입안을 행군 후 다른 시료를 평가하도록 지시하였 다(강원대학교 생명윤리위원회 승인번호: KWNUIRB-201910-005-001).

관능 항목은 단단한 정도인 경도(hardness), 반복 저작하였 을 때 이전의 조직감을 유지하는 정도인 응집성(cohesiveness), 떡의 촉촉한 정도(moistness), 색도(color), 전반적인 기 호도(overall preference)에 대하여 진행하였다. 점수는 7점 점수법에 따라 평가하였으며, 기호도가 높을수록 7점에 가까 운 점수를 주도록 설계하였다.

\section{통계처리}

실험에서 얻어진 결과 값은 SPSS(SPSS ver.18, SPSS Inc., Chicago, IL, USA)를 이용하여 통계처리를 하였으며 Duncan의 다중범위검정법(Duncan's multiple range test)으 로 유의성을 검증하였다 $(\mathrm{p}<0.05)$. 


\section{결과 및 고찰}

\section{쌀 수침 시 수분평형 도달 시간}

수침 시간에 따른 쌀의 수분 함량 변화를 Fig. 1에 나타내 었다. 건조된 쌀을 $15,30,45,60,120,240$ 분간 수침한 쌀의 수분함량을 측정한 결과, 수침 후 60 분까지는 수침시간에 따 라 유의미하게 증가하였으나, 그 이후에는 내부의 수분함량 이 증가하지 않는 평형상태에 도달하였음을 알 수 있다. 이는 찹쌀, 현미, 보리의 경우, 수침 온도와 관계없이 평형수분함 량에 도달하는 시간이 1 시간으로 보고된 연구결과와 일치하 는 결과이다(Park 등, 2006; Yu와 Han, 2004). 이에 따라 연 구에 사용된 수침 후 분쇄를 통하여 얻어진 미분 제조 시 수 침시간은 1 시간으로 고정하여 적용하였다.

\section{분쇄 및 입자도}

압출 떡 제조 시에 미분 입자의 크기가 미치는 영향을 조 사하기 위하여 시중에서 구매한 건조미분(이후 건조미분으로 칭함)과 수침 후 분쇄하여 제조한 미분(수화미분)의 입자의 크기를 측정하여 비교하였다(Fig. 2). 건조미분의 경우, 0.43$0.6 \mathrm{~mm}$ 의 입자가 $63 \%$ 로 가장 높은 비율을 나타낸 반면, 실 험실에서 제작한 수화미분의 경우 $1 \mathrm{~mm}$ 이상을 차지하는 입 자크기의 누적량이 $90 \%$ 를 차지하는 것을 확인하였다. 수화 미분의 평균입자가 건조미분보다 큰 것을 알 수 있다. 이는 실험실에서 수침하여 제조하는 쌀을 이용할 경우, 압출 떡 제 조 시에 사용되는 쌀가루의 입자가 대량생산에 사용되는 상 용화된 쌀가루보다 큰 입자를 사용하게 됨을 의미한다.

\section{수분 함량}

압출 떡의 수분함량은 떡의 조직감과 색도 및 유통기한에 중요한 역할을 하는 인자이다. 수침을 진행한 쌀을 분쇄한 실 험실 단위 미분은 입자 크기뿐만 아니라 수분 함량 또한 다르 기 때문에 기존의 배합비와 다른 배합비를 적용해야 한다(Yu

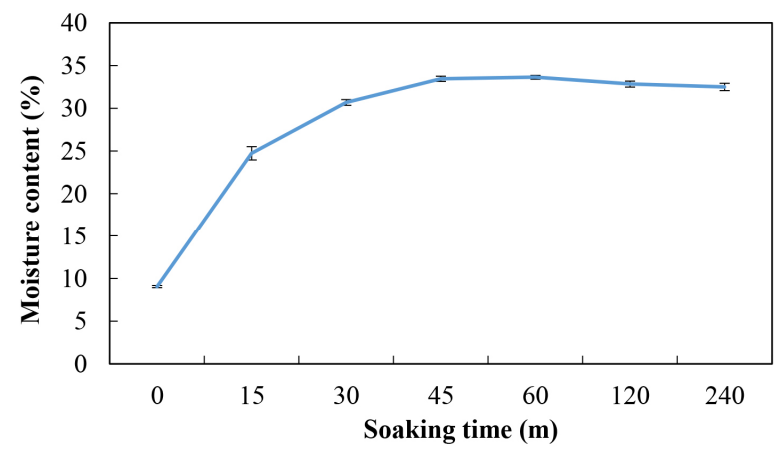

Fig. 1. Changes in moisture content of rice grain during soaking.
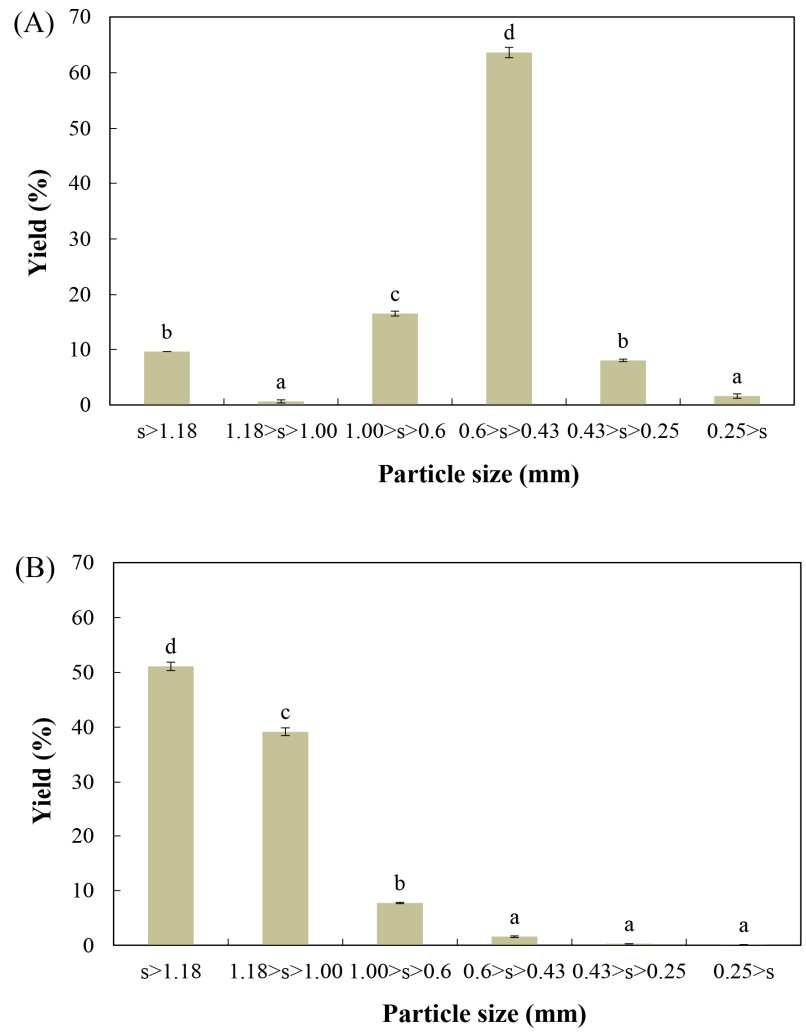

Fig. 2. Particle size distribution of rice flour.

A, dried rice flour; $\mathrm{B}$, hydrated rice flour.

The symbol 's' indicates the particle size of rice flours. Bars marked different letter indicates that values were significantly different among the extrusion conditions $(\mathrm{p}<0.05)$.

와 Han, 2004). 수분 함량이 너무 낮거나 너무 높은 경우, 정 상적으로 떡을 압출할 수 없으며, 수분 함량은 조직감에 영향 을 미치는 요소 중 하나이기 때문에 실험실 단위 미분에 적합 한 배합비의 도출은 필수적인 사항이다(Kang 등, 2012b).

압출 떡의 압출 조건인 증자시간과 압출횟수에 따른 압출 떡 시료의 수분 함량은 Fig. 3 과 같다. 먼저 건조미분을 사용 하여 배합비에 첨가된 쌀과 수분의 비율은 1:0.4와 1:0.5로 조절하여 압출공정에 따른 최종 수분함량을 Fig. $3 \mathrm{~A}$ 와 Fig. $3 \mathrm{~B}$ 에서 각각 나타내었다. 건조 미분에 첨가된 수분함량이 많 을수록 압출 떡의 수분함량이 높으며, 또한 증자시간이 증가 함에 따라 압출 떡에 포함되는 수분함량이 높아짐을 알 수 있다. 이는 떡볶이 가래떡을 이용하여 떡의 수분함량 변화에 대한 연구결과와 동일한 결과이다(Kang 등, 2012b). 반면, 압 출횟수는 최종수분함량에 유의미하지 않은 영향을 주거나, 증 자시간이 짧은 경우는 오히려 압출횟수의 증가에 따라 최종 수분함량이 감소하는 모습을 보여주었다. 수화미분 $30 \%$ 수 분함량)으로 압출한 떡의 경우, 배합비의 전체수분 함량은 $1: 0.4$ 와 동일하나, 최종 압출 떡의 수분함량 범위는 $48-50 \%$ 


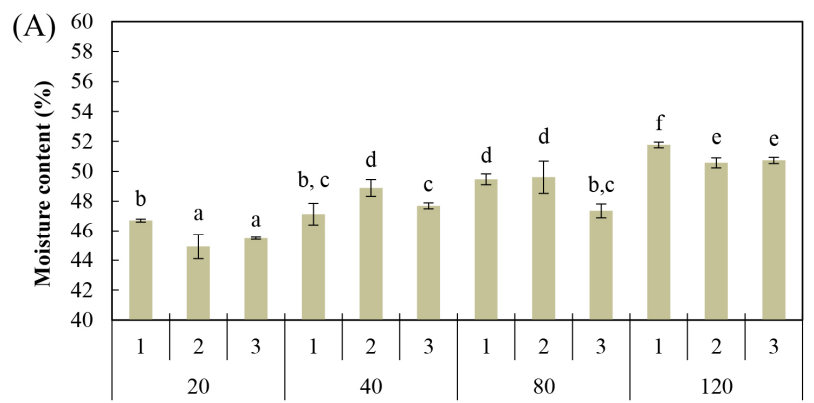

Number of extrusion \& steaming time (min)

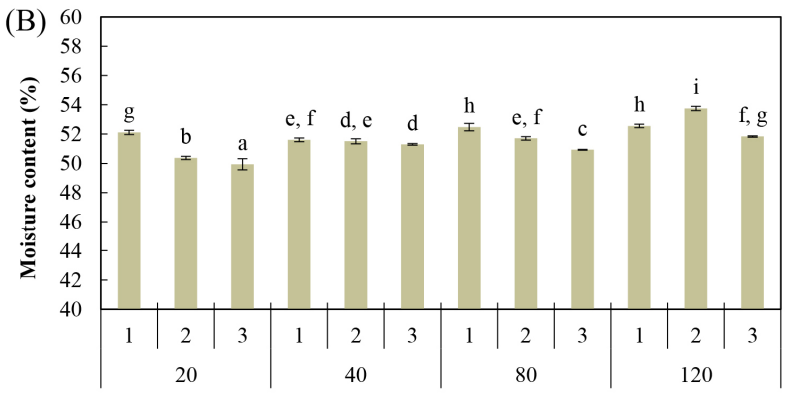

Number of extrusion \& steaming time (min)

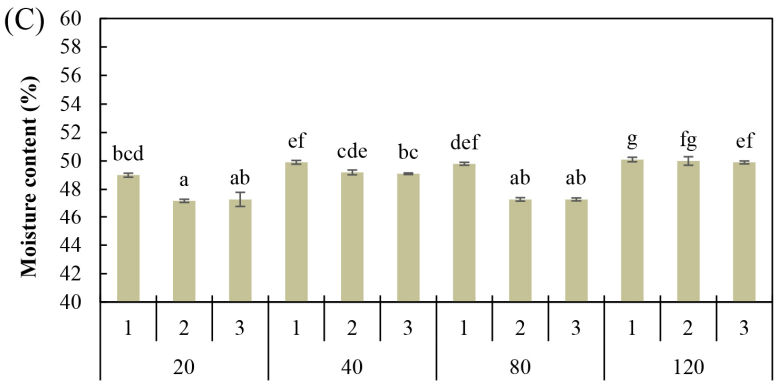

Number of extrusion \& steaming time (min)

Fig. 3. Moisture content of extruded rice cakes according to the number of extrusion and steaming time.

A, dried rice flour:water content $=1: 0.4 ; \mathrm{B}$, dried rice flour:moisture $=1: 0.5 ; \mathrm{C}$, hydrated rice flour.

Bars marked same letter indicates that values were not significantly different among the extrusion conditions $(\mathrm{p}>0.05)$.

인 것을 나타내었으며, 이는 수침으로 미분이 완전히 수화된 상태로 증자와 압출이 되었기 때문으로 사료된다. 압출공정 에 따른 수분함량의 변화와 관련된 Kang 등(2012b)의 연구에 따르면 압출횟수에 따라 수분함량이 유의적으로 증가된 보고 가 있다. 이는 압출 떡의 제조 시 압출 뒤 냉각을 거쳐 다시 압출을 한 경우로서 냉각을 통한 수분방출이 최소화된 사례 로서 본 연구에서 수행한 증자 후 연속적인 압출방식과는 다 른 공정이 적용된 경우라 할 수 있다. 실제 압출 떡의 생산은 고온인 상태에서 반복적인 압출을 통하여 이루어지므로 본 연구에서도 압출횟수는 냉각 없이 압출된 온도를 유지한 채
지속적으로 반복되게 수행되었으며, 이 같은 고온에서 연속 적으로 노출되는 과정에서 증발을 통하여 수분이 일정부분 감소된 결과로 판단된다.

\section{조직감 측정}

배합비와 입자 크기가 다른 미분으로 압출한 떡 시료들에 대하여 증자시간과 압출횟수에 따른 조직감 변화를 배합비에 따라 Table $3,4,5$ 에 나타내었다. 수화미분의 경우, 자체적으 로 $30 \%$ 의 수분을 함유하고 있어 $5: 1$ 의 배합비를 사용하였으 며, 이 경우 건조미분을 1:0.4 배합한 시루와 동일한 수분을 함유하였다.

건조미분을 사용한 경우, 배합비 $1: 0.4$ 와 $1: 0.5$ 에서의 조직 감 변화는 유사한 경향을 보였다. 압출 떡의 hardness는 증자 시간이 증가할수록 유의적으로 감소하였으나, 압출횟수의 변 화로 인한 경도의 유의적 차이는 확인할 수 없었다. 증자시간 의 증가에 따른 hardness의 감소는 미분이 충분히 호화되므 로 불완전한 호화상태의 미분분말이 주는 경도(딱딱한 느낌) 가 줄어들어 발생하는 현상으로 사료된다(Yu와 Han, 2004). 추가적으로 최소 증자시간인 20분을 적용한 1:0.4의 배합비 를 적용한 떡의 경도가 1:0.5의 배합비를 사용한 떡보다 유의 적으로 높은 것을 확인하였다. 이는 떡 내부의 수분 함량이 높을수록 발생하는 수분확산으로 인해 입자 결합을 약화시켜 경도가 낮아진다고 보고한 선례연구와 일치하였다(Kang 등, 2012b). Adhesiveness의 경우, 압출 조건의 변화에 따른 값의 변화는 확인할 수 있었으나, 값이 불규칙하여 효능을 확인할 수 없었다. Cohesiveness는 압출횟수가 증가할수록 값이 유 의적으로 증가하는 것을 확인하였으나, 증자시간 20 분을 적 용한 시료에서는 확인할 수 없었다. Kang 등(2011)에 따르면 압출횟수가 증가할수록 미세 미분 입자는 감소하고, 기공의 크기는 작아지나 수는 많아진다고 보고하였다. 압출횟수의 증가에 따른 cohesiveness의 증가는 압출공정 중 사출구를 통 하여 압출되는 호화된 떡이 사출구의 내부 표면에서 받는 전 단력에 의하여 보다 조밀한 구조를 형성하게 되어 발생하는 현상으로 판단된다. Gumminess와 chewiness는 증자시간이 증가할수록 값이 유의적으로 감소하는 것을 확인하였으나, 압출횟수에 의한 유의적인 변화는 확인할 수 없었다. 이는 gumminess와 chewiness가 hardness값을 바탕으로 도출하는 값이므로 증자시간의 증가로 인한 hardness값의 감소로 인하 여 발생하는 것으로 사료된다. Gumminess와 chewiness는 두 인자 모두 hardness에 유의적인 영향을 받는다. 본 연구에서 gumminess는 hardness와 cohesiveness의 곱으로 도출하였으 며, chewiness는 1 회차 수직변형 시에 발생한 거리와 2 회차 수직변형 시에 발생한 거리 비와 gumminess의 곱으로 도출 하였다. 따라서 증자시간의 증가로 hardness가 감소할 때 
Table 3. Texture properties of rice cake samples prepared with dried rice flour : moisture $=1: 0.4$ according to the steaming time and the number of extrusion

\begin{tabular}{|c|c|c|c|c|c|c|}
\hline \multicolumn{2}{|c|}{ Parameter } & \multirow{2}{*}{$\begin{array}{l}\text { Hardness } \\
(\mathrm{g})\end{array}$} & \multirow{2}{*}{$\begin{array}{l}\text { Adhesiveness } \\
\qquad(\mathrm{g} \cdot \mathrm{s})\end{array}$} & \multirow[b]{2}{*}{ Cohesiveness } & \multirow[b]{2}{*}{ Gumminess } & \multirow[b]{2}{*}{ Chewiness } \\
\hline $\begin{array}{l}\text { Steaming time } \\
\quad(\min )\left(X_{1}\right)\end{array}$ & $\begin{array}{c}\text { Number of } \\
\text { extrusion }\left(X_{2}\right)\end{array}$ & & & & & \\
\hline \multirow{3}{*}{20} & 1 & $800.7 \pm 137.2^{\mathrm{a} 1)}$ & $206.4 \pm 59.3^{\mathrm{ab}}$ & $0.87 \pm 0.02^{\mathrm{ab}}$ & $480.0 \pm 67.3^{\mathrm{a}}$ & $319.8 \pm 104.2^{b}$ \\
\hline & 2 & $834.4 \pm 172.8^{\mathrm{a}}$ & $172.5 \pm 52.0^{\mathrm{abc}}$ & $0.89 \pm 0.03^{\mathrm{abc}}$ & $527.3 \pm 80.5^{\mathrm{a}}$ & $371.7 \pm 112.4^{\mathrm{ab}}$ \\
\hline & 3 & $865.0 \pm 153.6^{\mathrm{a}}$ & $178.1 \pm 89.2^{\mathrm{abc}}$ & $0.88 \pm 0.02^{\mathrm{abc}}$ & $375.1 \pm 73.0^{\mathrm{bc}}$ & $436.8 \pm 183.5^{\mathrm{a}}$ \\
\hline \multirow{3}{*}{40} & 1 & $540.8 \pm 43.19^{b}$ & $95.5 \pm 8.0^{\mathrm{de}}$ & $0.86 \pm 0.03^{\mathrm{a}}$ & $388.7 \pm 134.7^{\mathrm{bc}}$ & $228.1 \pm 37.6^{\mathrm{cd}}$ \\
\hline & 2 & $580.4 \pm 57.1^{\mathrm{b}}$ & $126.5 \pm 3.5^{\mathrm{bcdf}}$ & $0.90 \pm 0.03^{\text {bcd }}$ & $447.2 \pm 102.7^{\mathrm{ab}}$ & $242.9 \pm 41.3^{\mathrm{cd}}$ \\
\hline & 3 & $580.1 \pm 124.1^{\mathrm{b}}$ & $195.4 \pm 37.5^{\mathrm{a}}$ & $0.92 \pm 0.01^{\mathrm{d}}$ & $482.8 \pm 140.4^{\mathrm{bc}}$ & $243.5 \pm 62.9^{\text {cd }}$ \\
\hline \multirow{3}{*}{80} & 1 & $380.8 \pm 170.9^{c}$ & $121.0 \pm 15.8^{\text {cde }}$ & $0.92 \pm 0.04^{\mathrm{d}}$ & $350.5 \pm 146.2^{\mathrm{c}}$ & $216.4 \pm 135.6^{\mathrm{d}}$ \\
\hline & 2 & $386.5 \pm 60.3^{\mathrm{c}}$ & $108.9 \pm 8.2^{\mathrm{de}}$ & $0.92 \pm 0.03^{\mathrm{d}}$ & $372.2 \pm 57.6^{\mathrm{bc}}$ & $177.8 \pm 53.0^{\mathrm{d}}$ \\
\hline & 3 & $354.9 \pm 87.5^{\mathrm{c}}$ & $131.0 \pm 10.5^{\mathrm{bcd}}$ & $0.97 \pm 0.06^{\mathrm{e}}$ & $370.7 \pm 78.3^{\mathrm{bc}}$ & $222.9 \pm 87.3^{\mathrm{d}}$ \\
\hline \multirow{3}{*}{120} & 1 & $167.6 \pm 51.6^{\mathrm{d}}$ & $181.7 \pm 34.0^{\mathrm{ab}}$ & $0.88 \pm 0.02^{\mathrm{abc}}$ & $212.3 \pm 32.8^{\mathrm{d}}$ & $70.8 \pm 21.9^{\mathrm{e}}$ \\
\hline & 2 & $158.1 \pm 41.0^{\mathrm{d}}$ & $133.5 \pm 46.0^{\mathrm{bcd}}$ & $0.91 \pm 0.01^{\mathrm{cd}}$ & $147.2 \pm 25.3^{\mathrm{d}}$ & $57.0 \pm 17.6^{\mathrm{e}}$ \\
\hline & 3 & $130.4 \pm 24.0^{\mathrm{d}}$ & $71.6 \pm 29.2^{\mathrm{e}}$ & $0.92 \pm 0.02^{\mathrm{d}}$ & $171.0 \pm 54.5^{\mathrm{d}}$ & $85.1 \pm 45.2^{\mathrm{e}}$ \\
\hline
\end{tabular}

${ }^{1)}$ All data are reported as the mean \pm SE $(n=10)$. Values marked with different subscript indicates that values were not significantly different among the extrusion conditions $(\mathrm{p}<0.05)$.

Table 4. Texture properties of rice cake samples prepared with dried rice flour : moisture $=1: 0.5$ according to the steaming time and the number of extrusion

\begin{tabular}{|c|c|c|c|c|c|c|}
\hline \multicolumn{2}{|c|}{ Parameter } & \multirow[b]{2}{*}{$\begin{array}{l}\text { Hardness } \\
\text { (g) }\end{array}$} & \multirow[b]{2}{*}{$\begin{array}{l}\text { Adhesiveness } \\
(\mathrm{g} \cdot \mathrm{s})\end{array}$} & \multirow[b]{2}{*}{ Cohesiveness } & \multirow[b]{2}{*}{ Gumminess } & \multirow[b]{2}{*}{ Chewiness } \\
\hline $\begin{array}{l}\text { Steaming time } \\
\quad(\min )\left(X_{1}\right)\end{array}$ & $\begin{array}{l}\text { Number of } \\
\text { extrusion }\left(X_{2}\right)\end{array}$ & & & & & \\
\hline \multirow{3}{*}{20} & 1 & $762.4 \pm 124.2^{\mathrm{a} 1)}$ & $166.7 \pm 51.4^{\text {cde }}$ & $0.77 \pm 0.03^{\mathrm{a}}$ & $620.0 \pm 65.8^{\mathrm{a}}$ & $309.5 \pm 59.5^{\mathrm{b}}$ \\
\hline & 2 & $634.0 \pm 107.0^{\mathrm{b}}$ & $219.4 \pm 25.7^{\mathrm{a}}$ & $0.86 \pm 0.03^{\mathrm{d}}$ & $620.7 \pm 61.7^{\mathrm{a}}$ & $399.9 \pm 54.9^{\mathrm{a}}$ \\
\hline & 3 & $617.4 \pm 134.1^{\mathrm{bc}}$ & $207.2 \pm 12.4^{\mathrm{ab}}$ & $0.92 \pm 0.01^{\mathrm{e}}$ & $459.3 \pm 44.1^{\mathrm{cd}}$ & $326.8 \pm 35.8^{\mathrm{b}}$ \\
\hline \multirow{3}{*}{40} & 1 & $545.8 \pm 30.4^{\mathrm{c}}$ & $95.4 \pm 16.0^{\mathrm{g}}$ & $0.78 \pm 0.02^{\mathrm{ab}}$ & $440.3 \pm 22.7^{\mathrm{c}}$ & $227.1 \pm 18.5^{\mathrm{d}}$ \\
\hline & 2 & $592.7 \pm 30.2^{\mathrm{bc}}$ & $123.1 \pm 11.9^{\mathrm{feg}}$ & $0.79 \pm 0.02^{\mathrm{ab}}$ & $495.3 \pm 23.0^{\mathrm{b}}$ & $262.8 \pm 18.6^{\mathrm{c}}$ \\
\hline & 3 & $616.0 \pm 74.0^{\mathrm{bc}}$ & $179.9 \pm 60.6^{\mathrm{bc}}$ & $0.80 \pm 0.03^{\mathrm{bc}}$ & $557.6 \pm 41.2^{\mathrm{b}}$ & $275.0 \pm 48.6^{\mathrm{c}}$ \\
\hline \multirow{3}{*}{80} & 1 & $468.6 \pm 118.2^{d}$ & $133.8 \pm 31.5^{\operatorname{defg}}$ & $0.76 \pm 0.01^{\mathrm{a}}$ & $424.3 \pm 38.8^{\mathrm{d}}$ & $214.3 \pm 35.9^{\mathrm{d}}$ \\
\hline & 2 & $394.5 \pm 83.5^{\mathrm{e}}$ & $104.6 \pm 20.2^{\mathrm{eg}}$ & $0.82 \pm 0.01^{\mathrm{c}}$ & $373.1 \pm 63.6^{\mathrm{d}}$ & $175.0 \pm 35.3^{\mathrm{e}}$ \\
\hline & 3 & $378.3 \pm 81.4^{\mathrm{e}}$ & $116.0 \pm 26.6^{\mathrm{feg}}$ & $0.87 \pm 0.02^{\mathrm{d}}$ & $337.4 \pm 55.1^{\mathrm{d}}$ & $167.1 \pm 56.2^{\mathrm{e}}$ \\
\hline \multirow{3}{*}{120} & 1 & $130.4 \pm 27.2^{\mathrm{f}}$ & $166.3 \pm 49.2^{\mathrm{cd}}$ & $0.96 \pm 0.04^{f}$ & $131.3 \pm 23.3^{\mathrm{e}}$ & $57.1 \pm 17.5^{\mathrm{f}}$ \\
\hline & 2 & $132.5 \pm 28.9^{f}$ & $142.6 \pm 48.8^{\text {feg }}$ & $0.96 \pm 0.04^{\mathrm{f}}$ & $126.3 \pm 25.7^{\mathrm{e}}$ & $65.4 \pm 26.0^{\mathrm{f}}$ \\
\hline & 3 & $125.6 \pm 29.1^{\mathrm{f}}$ & $138.2 \pm 43.3^{\mathrm{def}}$ & $0.98 \pm 0.02^{\mathrm{f}}$ & $106.8 \pm 13.7^{\mathrm{e}}$ & $55.6 \pm 11.0^{\mathrm{f}}$ \\
\hline
\end{tabular}

${ }^{1)}$ All data are reported as the mean \pm SE $(n=10)$. Values marked with different subscript indicates that values were not significantly different among the extrusion conditions $(\mathrm{p}<0.05)$. 
Table 5. Texture properties of rice cake samples prepared with hydrated rice flour according to the steaming time and the number of extrusion

\begin{tabular}{|c|c|c|c|c|c|c|}
\hline \multicolumn{2}{|c|}{ Parameter } & \multirow[b]{2}{*}{$\begin{array}{l}\text { Hardness } \\
(\mathrm{g})\end{array}$} & \multirow[b]{2}{*}{$\begin{array}{l}\text { Adhesiveness } \\
\qquad(\mathrm{g} \cdot \mathrm{s})\end{array}$} & \multirow[b]{2}{*}{ Cohesiveness } & \multirow[b]{2}{*}{ Gumminess } & \multirow[b]{2}{*}{ Chewiness } \\
\hline $\begin{array}{l}\text { Steaming time } \\
\quad(\min )\left(X_{1}\right)\end{array}$ & $\begin{array}{l}\text { Number of } \\
\text { extrusion }\left(X_{2}\right)\end{array}$ & & & & & \\
\hline \multirow{3}{*}{20} & 1 & $684.1 \pm 59.5^{\mathrm{a} 1)}$ & $144.2 \pm 51.9^{\mathrm{bc}}$ & $0.69 \pm 0.01^{\mathrm{a}}$ & $472.4 \pm 44.2^{\mathrm{c}}$ & $357.0 \pm 43.8^{\mathrm{c}}$ \\
\hline & 2 & $734.0 \pm 50.7^{\mathrm{a}}$ & $207.4 \pm 21.7^{\mathrm{de}}$ & $0.83 \pm 0.01^{\mathrm{c}}$ & $578.5 \pm 30.6^{\mathrm{a}}$ & $541.4 \pm 46.3^{\mathrm{a}}$ \\
\hline & 3 & $736.0 \pm 103.5^{\mathrm{a}}$ & $204.9 \pm 27.4^{\mathrm{cd}}$ & $0.86 \pm 0.02^{\mathrm{d}}$ & $494.6 \pm 81.9^{b}$ & $455.7 \pm 82.5^{\mathrm{b}}$ \\
\hline \multirow{3}{*}{40} & 1 & $441.9 \pm 46.6^{\mathrm{bc}}$ & $181.2 \pm 65.9^{\mathrm{cd}}$ & $0.80 \pm 0.01^{\mathrm{b}}$ & $360.9 \pm 32.2^{\text {de }}$ & $329.4 \pm 34.8^{\mathrm{cd}}$ \\
\hline & 2 & $479.5 \pm 80.4^{\mathrm{b}}$ & $200.9 \pm 33.1^{\mathrm{de}}$ & $0.82 \pm 0.01^{\mathrm{bc}}$ & $340.9 \pm 49.6^{\mathrm{de}}$ & $308.2 \pm 50.5^{\text {cdef }}$ \\
\hline & 3 & $459.5 \pm 57.4^{\mathrm{bc}}$ & $100.6 \pm 29.1^{\mathrm{a}}$ & $0.82 \pm 0.01^{\mathrm{c}}$ & $379.3 \pm 50.1^{\mathrm{d}}$ & $310.7 \pm 41.7^{\text {cde }}$ \\
\hline \multirow{3}{*}{80} & 1 & $403.3 \pm 42.9^{c}$ & $169.7 \pm 29.5^{\mathrm{cd}}$ & $0.84 \pm 0.01^{\mathrm{d}}$ & $322.5 \pm 19.0^{\mathrm{ef}}$ & $278.6 \pm 18.9^{\operatorname{def}}$ \\
\hline & 2 & $443.2 \pm 61.0^{\mathrm{bc}}$ & $231.3 \pm 50.1^{\mathrm{e}}$ & $0.89 \pm 0.01^{\mathrm{e}}$ & $287.1 \pm 57.8^{\mathrm{fg}}$ & $320.0 \pm 63.9^{\text {cde }}$ \\
\hline & 3 & $416.3 \pm 74.1^{\mathrm{bc}}$ & $214.1 \pm 33.2^{\mathrm{de}}$ & $0.89 \pm 0.01^{\mathrm{e}}$ & $268.3 \pm 38.5^{\mathrm{g}}$ & $311.9 \pm 63.9^{\text {cde }}$ \\
\hline \multirow{3}{*}{120} & 1 & $322.2 \pm 72.8^{\mathrm{d}}$ & $179.4 \pm 53.2^{\mathrm{cd}}$ & $0.82 \pm 0.03^{\mathrm{bc}}$ & $287.6 \pm 76.3^{\text {fg }}$ & $272.7 \pm 61.1^{\mathrm{ef}}$ \\
\hline & 2 & $325.1 \pm 47.5^{\mathrm{d}}$ & $111.9 \pm 19.2^{\mathrm{ab}}$ & $0.82 \pm 0.01^{\mathrm{bc}}$ & $356.7 \pm 62.6^{\mathrm{de}}$ & $255.4 \pm 38.5^{\mathrm{f}}$ \\
\hline & 3 & $318.0 \pm 80.6^{\mathrm{d}}$ & $155.2 \pm 53.3^{\mathrm{c}}$ & $0.88 \pm 0.01^{\mathrm{e}}$ & $335.7 \pm 61.9^{\mathrm{def}}$ & $284.5 \pm 79.2^{\mathrm{def}}$ \\
\hline
\end{tabular}

${ }^{1)}$ All data are reported as the mean \pm SE $(n=10)$. Values marked with different subscript indicates that values were not significantly different among the extrusion conditions $(\mathrm{p}<0.05)$.

gumminess와 chewiness 또한 감소한 것으로 사료된다.

수화미분을 사용하여 제조한 압출 떡도 유사한 경향을 나 타내었으나, 증자시간에 따른 유의미한 차이는 건조미분을 사용한 경우와 다른 결과를 보였다. 수화미분을 사용한 경우, hardness는 증자시간이 증가할수록 유의적으로 감소하였으 나, 40 분과 80 분의 증자시간을 적용한 경우 hardness값의 유 의적인 차이는 확인할 수 없었다. 이는 수화미분의 경우, 상대 적으로 건조미분에 비하여 입자의 크기가 크며, 큰 입자에 호 화 이전 단계에서 이미 쌀 전분에 충분히 수분이 수화된 상태 이므로 상대적으로 증자시간에 따른 호화도의 영향을 적게 받으며, 짧은 시간에 충분한 호화에 의한 hardness의 감소가 이루어졌기 때문으로 사료된다. Hardness값에 영향을 받는 gumminess와 chewiness 또한 40 분과 80 분의 증자시간 사이 값의 유의적인 변화를 확인할 수 없었으며, 이는 입자크기가 큰 미분을 사용하여 떡을 제조하였을 때 hardness가 더 높게 측정되었다는 선례연구의 결과와 일치하였다(Choi 등, 2005; Lee 등, 2015). 선례연구에서는 입자 크기가 작은 미분의 경 우, 전분으로 구성된 조직이 차지하는 비율이 적어 외부의 변 형에 붕괴가 쉽게 발생하는 반면, 입자 크기가 큰 미분의 경 우 상대적으로 구조를 유지하고 있어 외부의 변형에 의한 파 손정도가 낮아 미분 입자 크기에 따른 경도 및 조직감 값의 차이가 나타나는 것으로 해석하였다. 본 연구결과도 이와 유 사하게 입자 크기가 작은 미분으로 제조한 떡은 외부에 힘에
저항하는 정도가 낮은 수치의 경도를 나타내는 반면, 입자 크 기가 큰 미분으로 제조한 떡에서는 조직을 유지하여 붕괴가 잘 발생하지 않아 높은 경도를 나타내는 것으로 사료된다. Cohesiveness의 경우, 다른 시료들과 마찬가지로 압출횟수가 증가할수록 값이 유의적으로 증가하는 것을 확인하였으며, adhesiveness 값은 불규칙하여 압출 조건에 따른 효능을 확인 할 수 없었다.

\section{색도 및 색차}

압출 떡의 압출 조건에 따른 색도의 변화는 배합비 및 사 용 미분의 종류에 따라 유의적 차이를 확인할 수 없었으며, 색도를 측정하여 얻은 $\mathrm{L}^{*}, \mathrm{a}^{*}, \mathrm{~b}^{*}$ 값을 이용하여 떡볶이 떡 제품과의 색차를 도출하였다(Table 6). 압출 1 회차와 비교 시, 압출횟수가 증가할수록 $\Delta \mathrm{E}$ 값이 감소하는 것을 확인하였 으며, 궁극적으로 시중 떡 제품과 유사한 색도를 나타내는 것 을 확인하였다. 이러한 결과는 압출횟수에 따른 품질인자 측 정 시 유의미한 차이를 확인할 수 없었다는 결과를 얻은 선례 연구와 대조되는 결과이나, 이는 선례연구의 경우 1 회차 압 출 시의 결과를 비교하지 않은 2-4회 압출횟수 적용 시의 결 과만을 비교하였기 때문으로 사료된다(Bae 등, 2016). 본 연 구에서 또한 압출을 각각 2 회와 3 회 진행한 압출 떡 사이에 서는 압출횟수의 증가에 따른 색도 값의 유의적인 차이를 나 타내지 않았다. 압출을 1 회만 적용한 경우, 미세구조 기공의 
Table 6. Chromaticity of extruded rice cake by different extrusion circumstances

\begin{tabular}{|c|c|c|c|c|c|}
\hline \multicolumn{2}{|c|}{ Condition } & \multirow{2}{*}{$\begin{array}{c}\text { L* } \\
\text { (Lightness) }\end{array}$} & \multirow{2}{*}{$\begin{array}{c}\mathrm{a}^{*} \\
\text { (redness) }\end{array}$} & \multirow[b]{2}{*}{ b* (yellowness) } & \multirow{2}{*}{$\begin{array}{c}\Delta \mathrm{E} \\
\text { (color difference) }\end{array}$} \\
\hline $\begin{array}{l}\text { Steaming time } \\
\quad(\min )\left(X_{1}\right)\end{array}$ & $\begin{array}{c}\text { Number of } \\
\text { extrusion }\left(X_{2}\right)\end{array}$ & & & & \\
\hline \multirow{3}{*}{20} & 1 & $75.44 \pm 0.31^{\mathrm{bl})}$ & $-0.66 \pm 0.01^{\mathrm{c}}$ & $12.19 \pm 0.10^{\mathrm{d}}$ & 3.82 \\
\hline & 2 & $77.66 \pm 0.39^{\mathrm{d}}$ & $-0.66 \pm 0.01^{\mathrm{c}}$ & $11.52 \pm 0.08^{\mathrm{f}}$ & 1.67 \\
\hline & 3 & $78.49 \pm 0.43^{\mathrm{e}}$ & $-0.62 \pm 0.01^{\mathrm{b}}$ & $11.91 \pm 0.07^{\mathrm{e}}$ & 0.78 \\
\hline \multirow{3}{*}{40} & 1 & $79.17 \pm 0.17^{\mathrm{f}}$ & $-0.75 \pm 0.01^{\mathrm{e}}$ & $12.64 \pm 0.05^{\mathrm{b}}$ & 0.62 \\
\hline & 2 & $79.81 \pm 0.41^{\mathrm{gh}}$ & $-0.72 \pm 0.01^{\mathrm{d}}$ & $12.29 \pm 0.04^{\mathrm{cd}}$ & 0.61 \\
\hline & 3 & $79.69 \pm 0.25^{\mathrm{g}}$ & $-0.88 \pm 0.01^{\mathrm{h}}$ & $12.19 \pm 0.09^{d}$ & 0.48 \\
\hline \multirow{3}{*}{80} & 1 & $76.59 \pm 0.78^{\mathrm{c}}$ & $-0.96 \pm 0.03^{\mathrm{i}}$ & $13.30 \pm 0.18^{\mathrm{a}}$ & 2.9 \\
\hline & 2 & $80.14 \pm 0.42^{\mathrm{h}}$ & $-0.81 \pm 0.02^{\mathrm{g}}$ & $12.58 \pm 0.10^{\mathrm{b}}$ & 1.04 \\
\hline & 3 & $79.85 \pm 0.32^{\mathrm{gh}}$ & $-0.79 \pm 0.01^{\mathrm{f}}$ & $12.31 \pm 0.21^{\mathrm{c}}$ & 0.66 \\
\hline \multirow{3}{*}{120} & 1 & $74.72 \pm 0.26^{\mathrm{a}}$ & $-0.76 \pm 0.01^{\mathrm{e}}$ & $11.38 \pm 0.06^{\mathrm{g}}$ & 4.57 \\
\hline & 2 & $77.73 \pm 0.47^{\mathrm{d}}$ & $-0.66 \pm 0.01^{c}$ & $10.69 \pm 0.15^{\mathrm{i}}$ & 2.02 \\
\hline & 3 & $78.92 \pm 0.45^{\mathrm{f}}$ & $-0.60 \pm 0.01^{\mathrm{a}}$ & $11.28 \pm 0.07^{\mathrm{h}}$ & 0.82 \\
\hline
\end{tabular}

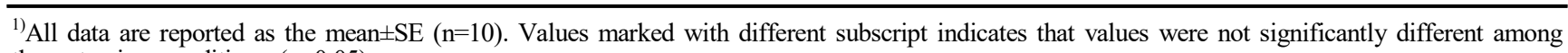
the extrusion conditions $(\mathrm{p}<0.05)$.

크기가 크고 불균일하기 때문에 선례 연구와 달리 압출횟수 의 증가에 따른 색도의 유의적인 차이가 나타난 것으로 사료 된다(Kang 등, 2011).

\section{모델 방정식 도출 및 최적화}

반응 표면 분석을 통해 증자시간 $\left(X_{1}\right)$ 과 압출횟수 $\left(X_{2}\right)$ 에 따 른 각 조직감 $(Y)$ 의 변화를 모델 식으로 도출하여 Table 7에 나타내었다. 도출한 모델 방정식들은 샘플 종류와 관계없이 공통적으로 hardness는 높은 상관계수 $\left(\mathrm{R}^{2}\right)$ 를 나타내었으며, 건조미분으로 제조한 압출 떡의 조직감 항목들은 모두 $\mathrm{R}^{2}$ 값 이 0.7 이상이며, p-value가 0.05 이하로 확인되어 유의성을 확인할 수 있었으나, 수화미분으로 제작한 떡 시료의 경우 hardness값과 cohesiveness값에서만 유의성을 확인할 수 있 었다(Yoon 등, 2017). 이는 두 미분시료간의 입자 크기 및 크 기 분포의 차이와 수화도의 차이로 인한 결과로 사료되며, 비 교적 입자크기의 분포도가 균일한 상용화된 건조미분을 이용 하는 것이 다양한 조직감 인자에 대하여 유의미한 모델식을 도출할 수 있다고 사료된다. 건조미분으로 제조한 떡 시료군 에서 hardness, gumminess, chewiness는 선형모델의 사용이 적합하였으며, adhesiveness와 cohesiveness는 2차모델의 사 용이 바람직한 것을 확인하였다. Hardness, gumminess, chewiness는 모두 증자시간 $\left(X_{1}\right)$ 에 의해서만 유의적인 영향을 나 타내었으며, adhesiveness는 $X_{1} * X_{2}$, cohesiveness는 $X_{1} * X_{2}{ }^{*} X_{1}^{2}$
총 3가지 인자에 의해 유의적인 영향을 나타내었다. 수화미 분을 사용하여 제조한 떡 시료군에서는 adhesiveness, gumminess, chewiness가 선형모델 사용이 적합하였으며, hardness 와 cohesiveness는 2 차모델의 사용이 적합하였다. 건조미분 샘플군과 마찬가지로 gumminess와 chewiness는 증자시간 $\left(X_{1}\right)$ 에 의해서만 유의적인 영향을 나타내었다. 수화미분을 사 용하여 제조한 떡 샘플군의 hardness는 $X_{1} * X_{1}^{2 *} X_{2}^{2}$ 에 의해 영 향을 받았으며, cohesiveness는 $X_{1}{ }^{*} X_{2}^{2}$ 에 의해 영향을 나타내 었으나, adhesiveness는 어떠한 인자도 영향을 주는 것을 확 인할 수 없었다. 도출된 모델 방정식에 따라 공정 조건인 증 자시간 $\left(X_{1}\right)$ 과 압출횟수 $\left(X_{2}\right)$ 에 따른 조직감의 변화를 등고선 도를 통하여 Fig. 4, 5, 6에 각 시료 별로 나타내었다.

\section{최적 압출 떡 공정의 도출}

본 연구의 목적은 압출 떡의 압출 조건을 조정하여 최종적 으로 시중에서 구매할 수 있는 떡볶이떡과 유사한 조직감을 가지는 압출 떡을 제조하는 공정을 찾는 것이므로 대조군으 로 시장에서 구매한 떡 견본의 조직감을 측정하여 본 연구에 서 개발된 공정의 결과와 비교하여 최적화된 공정조건을 도 출하는데 사용하였다(Table 8). 시장에서 구매한 떡볶이 떡의 hardness는 $176.01 \mathrm{~g}$, adhesiveness는 $293.15 \mathrm{~g} \cdot \mathrm{s}$, cohesiveness는 0.93, gumminess는 173.08, chewiness는 64.45로 측 정되었다. Hardness는 조직감 측정 당시 1회차 수직변형 중 
Table 7. Model equations to describe the texture properties of rice cake $(Y)$ according to the steaming time $\left(X_{I}\right)$ and the number of extrusion $\left(X_{2}\right)$

\begin{tabular}{|c|c|c|c|c|}
\hline Sample type & Parameter & Model & $\mathrm{R}^{2}$ & p-value \\
\hline \multirow{5}{*}{ 1:0.4 } & Hardness & $769.2-5.189 X_{1}-3.98 X_{2}$ & 0.98 & 0.01 \\
\hline & Adhesiveness & $176-1.465 X_{1}+102.3 X_{2}+0.00858 X_{1}^{2}+9.76 X_{2}^{2}-1.312 X_{1} X_{2}$ & 0.96 & 0.02 \\
\hline & Cohesiveness & $0.9424+0.00638 X_{1}+0.02585 X_{2}-0.03832 X_{1}^{2}$ & 0.91 & 0.01 \\
\hline & Gumminess & $583.2-3.284 X_{1}+12.2 X_{2}$ & 0.89 & 0.01 \\
\hline & Chewiness & $334.7-2.09 X_{1}+6 X_{2}$ & 0.86 & 0.01 \\
\hline \multirow{5}{*}{$1: 0.5$} & Hardness & $820.0-5.692 X_{1}-4.2 X_{2}$ & 0.95 & 0.01 \\
\hline & Adhesiveness & $117.2-0.67 X_{1}+3.4 X_{2}+0.01426 X_{1}^{2}+14.8 X_{2}^{2}-0.704 X_{1} X_{2}$ & 0.87 & 0.03 \\
\hline & Cohesiveness & $0.8052-0.001138 X_{1}+0.01617 X_{2}+0.000021 X_{1}^{2}$ & 0.98 & 0.01 \\
\hline & Gumminess & $699.4-4.703 X_{1}+X_{2}$ & 0.91 & 0.01 \\
\hline & Chewiness & $357.4-2.445 X_{1}-0.1 X_{2}$ & 0.93 & 0.01 \\
\hline \multirow{5}{*}{ Lab scale flour } & Hardness & $365.5+1.258 X_{1}+93.9 X_{2}-0.01869 X_{1}^{2}-22.38 X_{2}^{2}$ & 0.98 & 0.01 \\
\hline & Adhesiveness & $203.8-0.15 X_{1}-10.1 X_{2}$ & 0.05 & 0.84 \\
\hline & Cohesiveness & $0.6305+0.00485 X_{1}+0.02127 X_{2}-0.000028 X_{1}^{2}$ & 0.82 & 0.02 \\
\hline & Gumminess & $331.6-0.552 X_{1}+4.91 X_{2}$ & 0.63 & 0.05 \\
\hline & Chewiness & $333.3-0.565 X_{1}+4.39 X_{2}$ & 0.64 & 0.04 \\
\hline
\end{tabular}

(A)

Contour Plot of Hardness vs Number of extrusion, Steaming time (m)

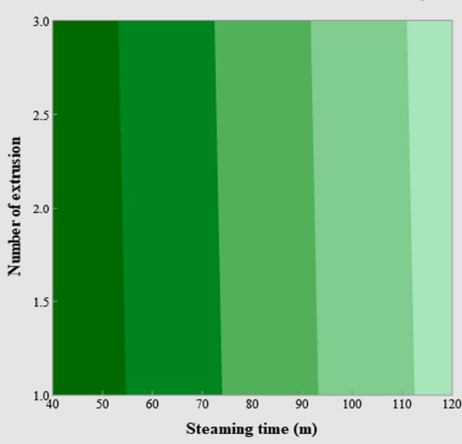

(C)
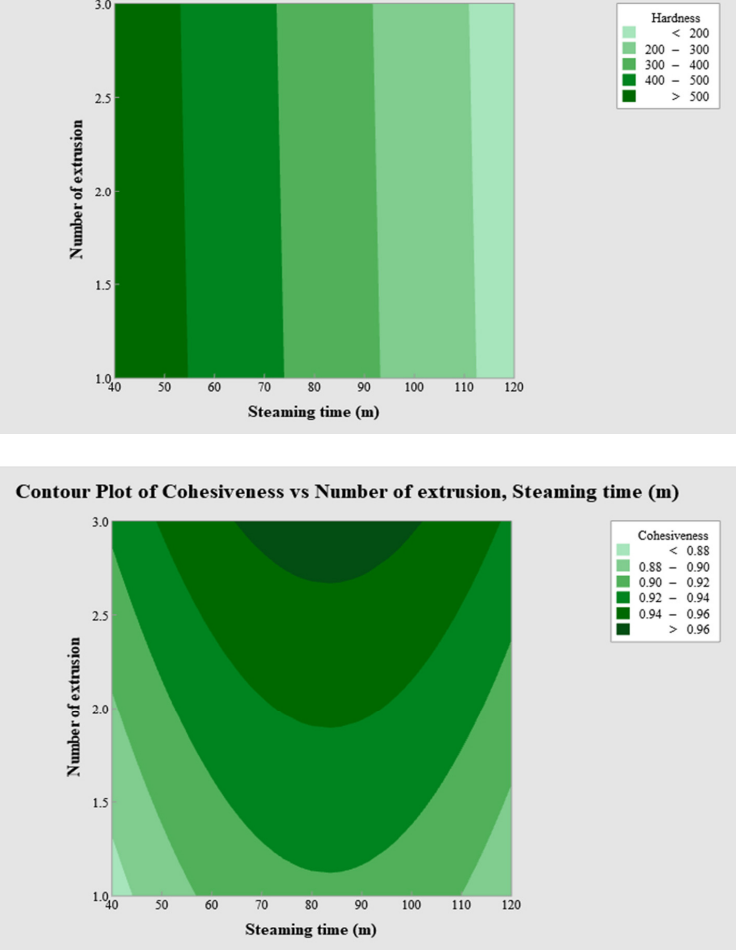

(B)

Contour Plot of Adhesiveness vs Number of extrusion, Steaming time (m)

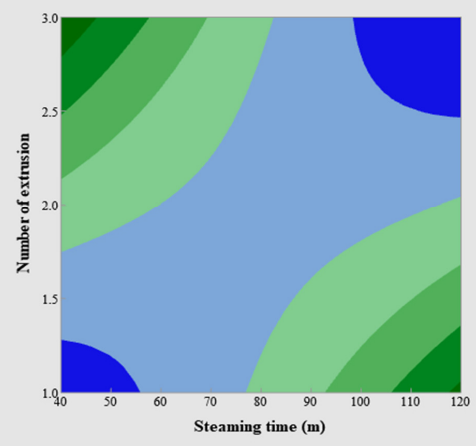

(D)

Contour Plot of Gumminess vs Number of extrusion, Steaming time (m)

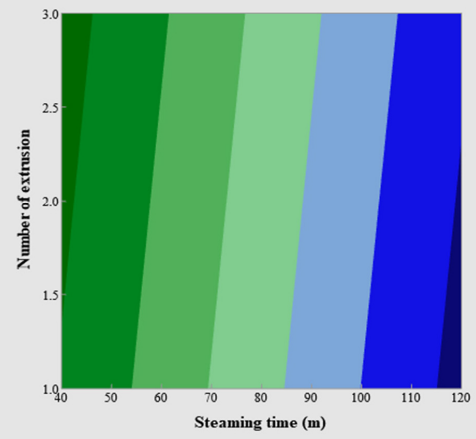

Fig. 4. Contour map of texture properties (A, hardness; B, adhesiveness; C, cohesiveness; D, gumminess; E, chewiness) of rice cake ( $Y$ ) prepared with dried rice flour:moisture $=1: 0.4$ according to the steaming time $\left(X_{1}\right)$ and the number of extrusions $\left(X_{2}\right)$. 
(E)

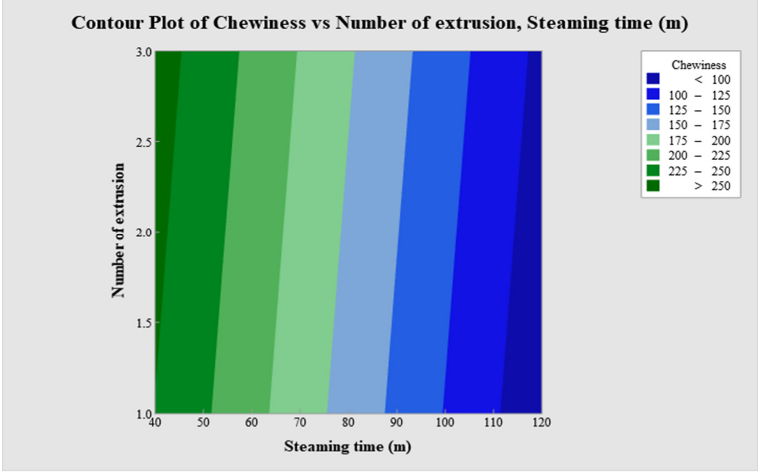

Fig. 4. Contour map of texture properties (A, hardness; B, adhesiveness; $C$, cohesiveness; D, gumminess; and $E$, chewiness) of rice cake ( $Y$ ) prepared with dried rice flour:moisture $=1: 0.4$ according to the steaming time $\left(X_{1}\right)$ and the number of extrusions $\left(X_{2}\right)$. $(C o n t i n u e d)$.

(A)

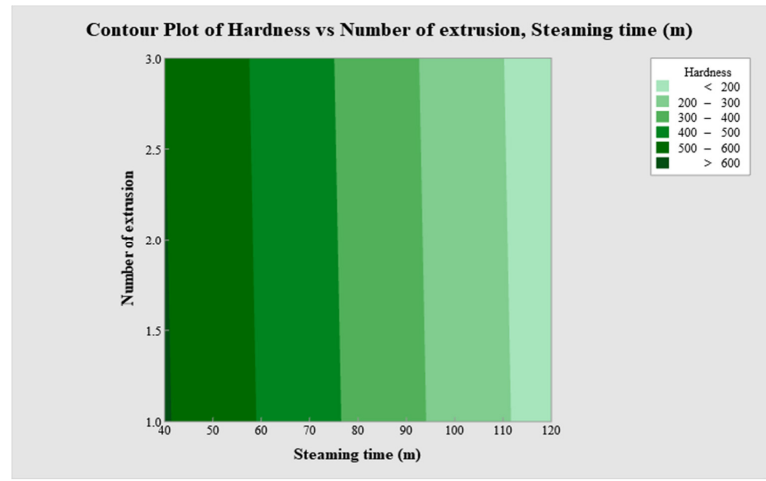

(C)

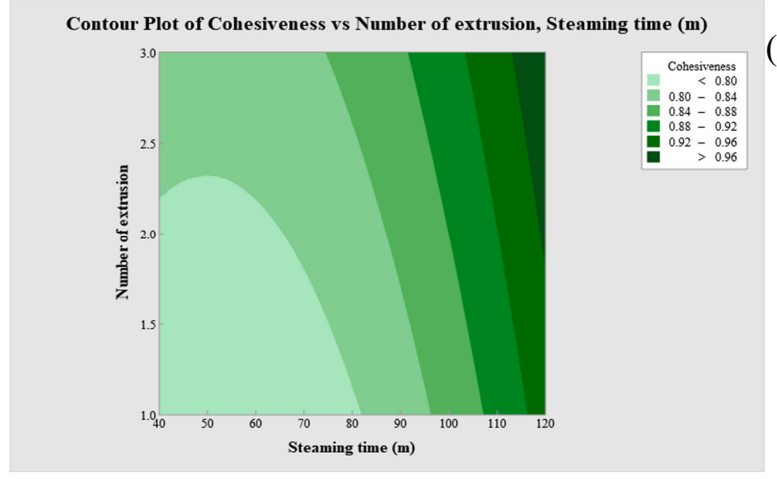

(E)

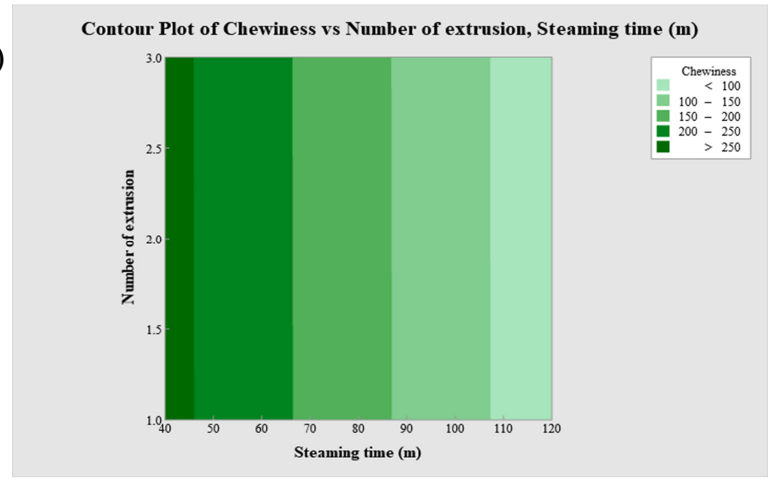

(B)

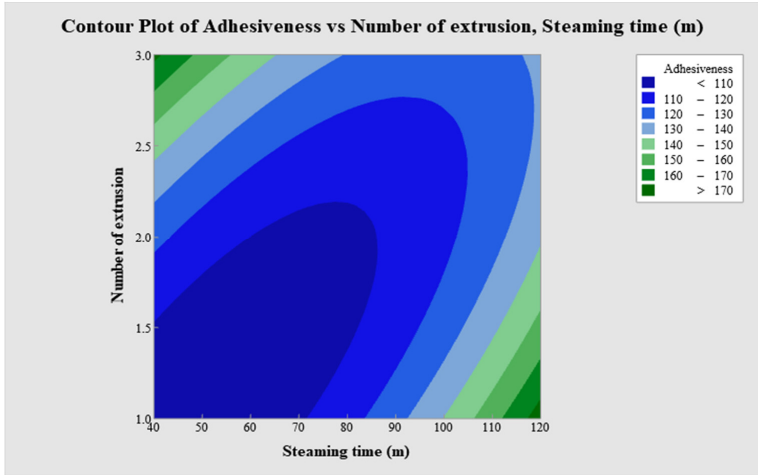

(D)

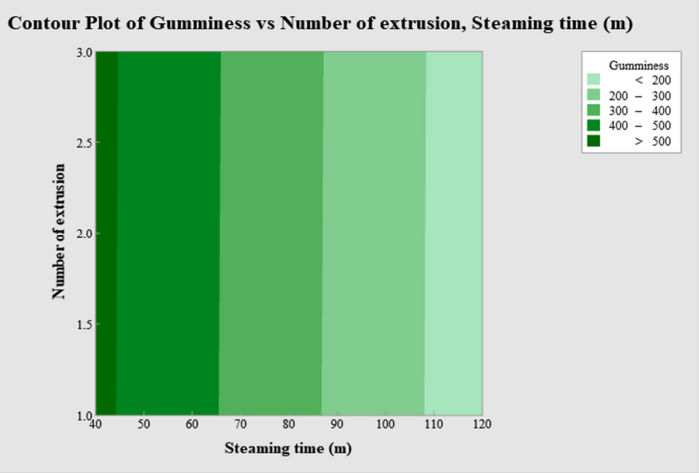

Fig. 5. Contour map of texture properties (A, hardness; B, adhesiveness; C, cohesiveness; D, gumminess; E, chewiness) of rice cake ( $Y$ ) made with solid content:moisture $=1: 0.5$ according to steaming time $\left(X_{1}\right)$ and number of extrusions $\left(X_{2}\right)$. 
(A)

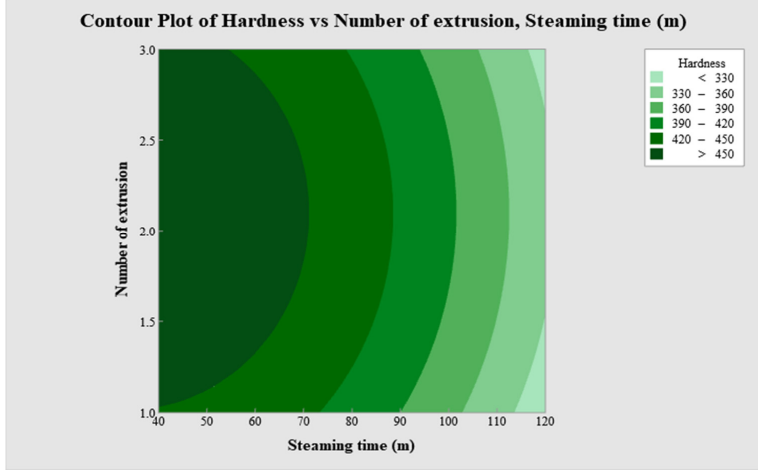

(C)

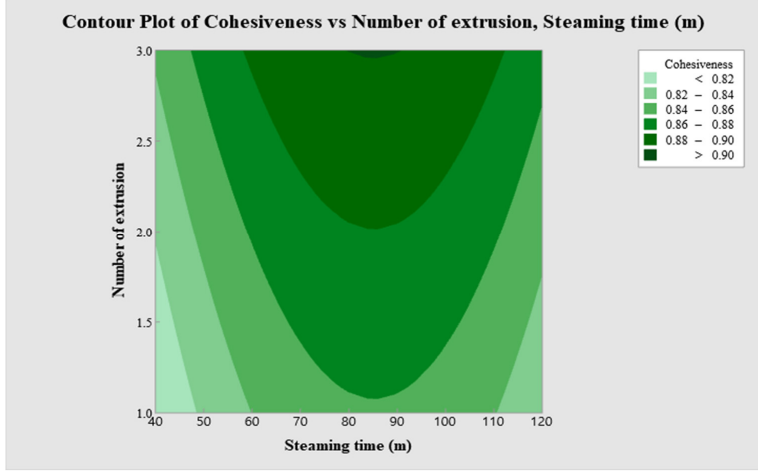

(E)

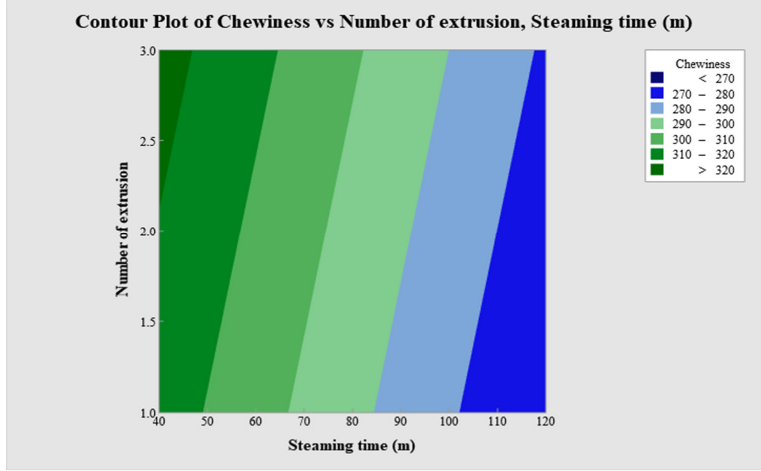

(B)

Contour Plot of Adhesiveness vs Number of extrusion, Steaming time (m)

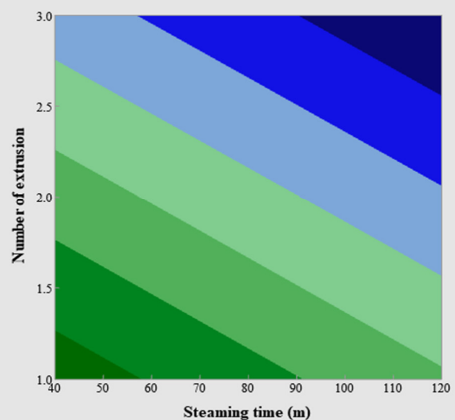

Contour Plot of Gumminess vs Number of extrusion, Steaming time (m)

(D)

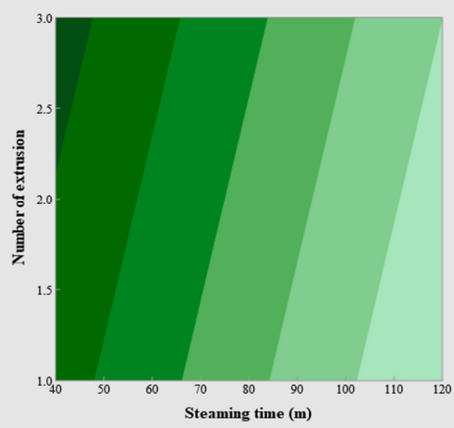

Fig. 6. Contour map of texture properties (A, hardness; B, adhesiveness; C, cohesiveness; D, gumminess; E, chewiness) of rice cake (I) prepared with hydrated rice flour according to steaming time $\left(X_{1}\right)$ and number of extrusions $\left(X_{2}\right)$.

도달하는 최고 힘을 의미하며, adhesiveness는 1회차 수직변 형 이후 프로브와 샘플이 떨어지는데 필요한 힘을 의미한다. Cohesiveness는 기존의 형태를 유지하고자 하는 힘으로써 1 회차 수직변형과 2회차 수직변형 시 발생하는 상단부의 면적 의 비로 계산하였다. Gumminess는 hardness와 gumminess의 곱으로 계산하였으며, chewiness는 gumminess와 1회차 수직 변형 시에 발생한 거리와 2회차 수직변형 시에 발생한 거리 비의 곱으로 계산하였다. 독립 변수로는 증자시간 $\left(X_{1}\right)$ 과 압출 횟수 $\left(X_{2}\right)$ 를 사용하였으며, 세 개의 시료[건조미분(1:0.4, 1:0.5) 과 수화미분]로 제조한 압출 떡에 대한 모델 방정식 중 $\mathrm{R}^{2}$ 값 이 0.7 이상이며, p-value가 0.05 이하인 항목들을 종속변수
로 사용하였다. 목표함수로는 시중 떡볶이 떡의 조직감 인자 를 설정하여 사용하였다(Fig. 7, 8, 9).

건조미분:수분의 비율이 1:0.4인 경우, 증자시간을 약 116 분, 압출횟수를 1 회 진행하였을 때 해당 배합비에서 가장 높 은 종합만족도를 나타내는 것을 확인하였으며(Fig. 7), 건조 미분:수분의 비율이 $1: 0.5$ 인 환경에서는 증자시간을 115 분, 압출횟수를 1 회 진행할 시 해당 배합비에서 가장 높은 종합 만족도를 나타내는 것을 확인하였다(Fig. 8). 이와 같은 최적 화과정을 거쳐 도출된 결과는 건조미분:수분함량의 차이를 $1: 0.4$ 와 $1: 0.5$ 로 할 경우 증자시간의 경우 최적 조직감을 나 타내기 위해서는 큰 차이가 나지 않는 값을 나타냈으며, 압출 
Table 8. Texture properties of commercial rice cakes

\begin{tabular}{cc}
\hline Parameter & Value \\
\hline Hardness & $176.01 \pm 11.17^{1)}$ \\
Adhesiveness & $293.15 \pm 41.25$ \\
Cohesiveness & $0.93 \pm 0.01$ \\
Gumminess & $173.08 \pm 3.93$ \\
Chewiness & $64.45 \pm 4.25$ \\
\hline
\end{tabular}

${ }^{1)}$ All data are reported as the mean \pm SE $(n=10)$.

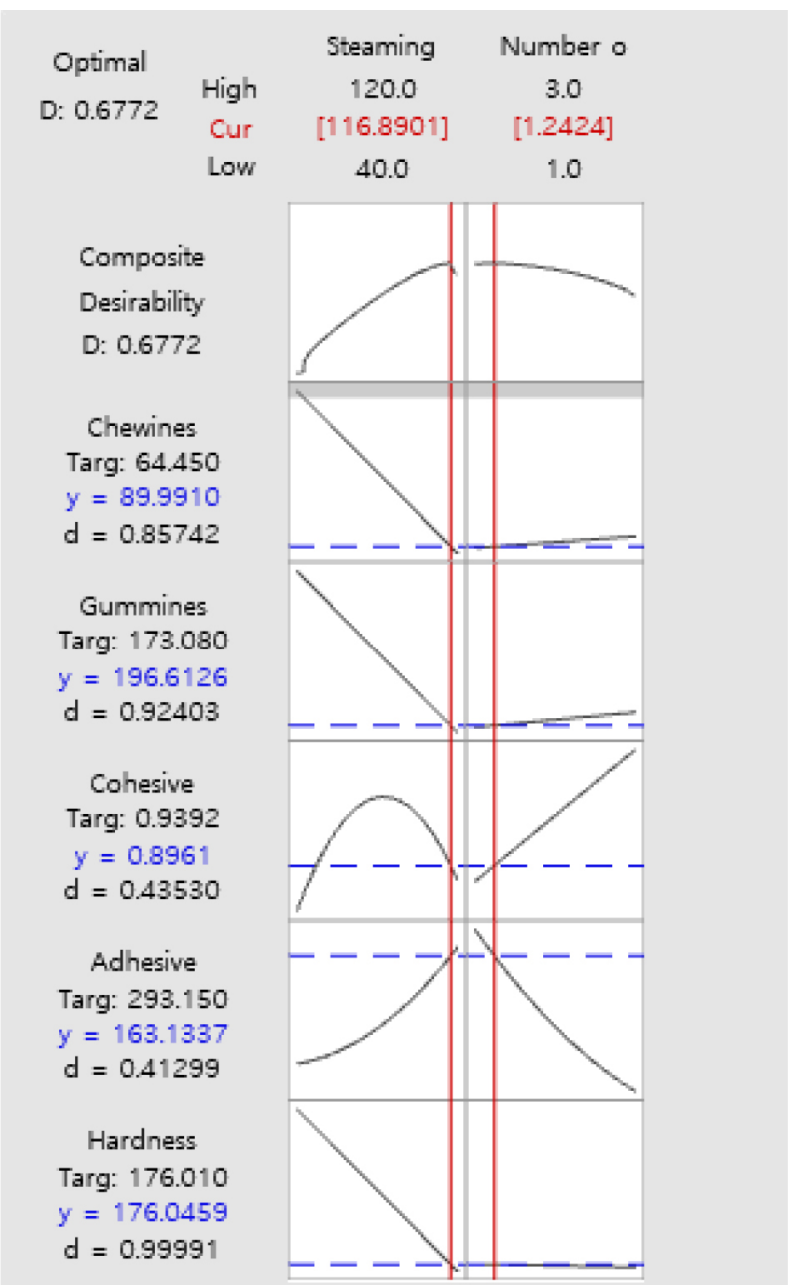

Fig. 7. Optimization of texture properties of rice cake $(Y)$ prepared with dried rice flour:moisture $=1: 0.4$ according to the steaming time $\left(X_{1}\right)$ and the number of extrusions $\left(X_{2}\right)$.

횟수는 유의미한 차이가 나지 않는 것을 확인하였다. 수화된 미분을 사용하여 제조한 압출 떡의 경우, 동일한 조건에서 최 적화를 진행하였을 때, 111 분의 증자시간과 3 회의 압출횟수 를 적용할 시 종합 만족도가 가장 높게 나타나 떡볶이 떡 제

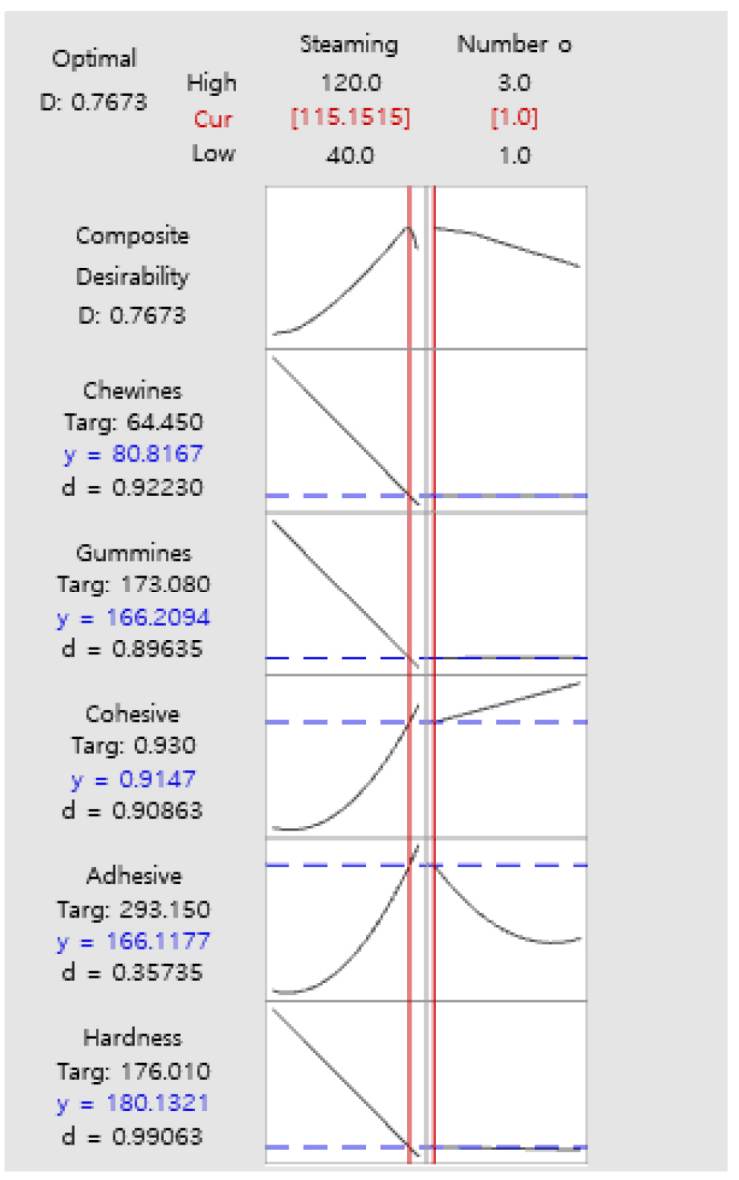

Fig. 8. Optimization of texture properties of rice cake $(Y)$ made with solid content:moisture $=1: 0.5$ according to steaming time $\left(X_{1}\right)$ and number of extrusions $\left(X_{2}\right)$.

품과 가장 유사한 조직감을 나타내는 것을 확인하였다. 종합 만족도의 경우 건조미분과 첨가 수분의 비율이 $1: 0.5$ 인 경우 0.76 으로 가장 높은 값을 나타내었으며, 수화미분으로 압출 한 떡이 0.49 로 가장 낮은 만족도를 나타내었다. 종합 만족도 는 목적함수를 만족하기 위하여 각 종속변수들이 목표치에 얼마나 근접한가를 수치화한 값으로 그 범위는 0 과 1 의 사이 이며, 최소치인 0 은 인자가 허용 한계치를 벗어났음을 의미 하며, 최대치는 1 은 가장 이상적인 상태를 나타낸다(Jung과 Lee, 2012). 건조미분과 첨가 수분의 비율이 1:0.5인 떡에서 종합만족도 0.76 로서 본 연구에서 설정한 목적함수인 시중 의 떡볶이 떡의 값에 가장 근접한 값을 나타내어 가장 이상 적인 조직감을 가진 압출 떡을 제조할 수 있음을 확인하였으 며, 반면 수화미분으로 떡을 제조 시 종합만족도 0.49 로서 이상적인 조직감으로 선정한 시중의 떡볶이 떡의 값과 가장 거리가 먼 압출 떡이 제조되는 것을 확인할 수 있었다. 종합 만족도, 증자시간 및 압출횟수를 고려한 떡 압출에 소요되는 총 시간, 수분 첨가로 인한 원료비 절감 등을 고려하였을 때 


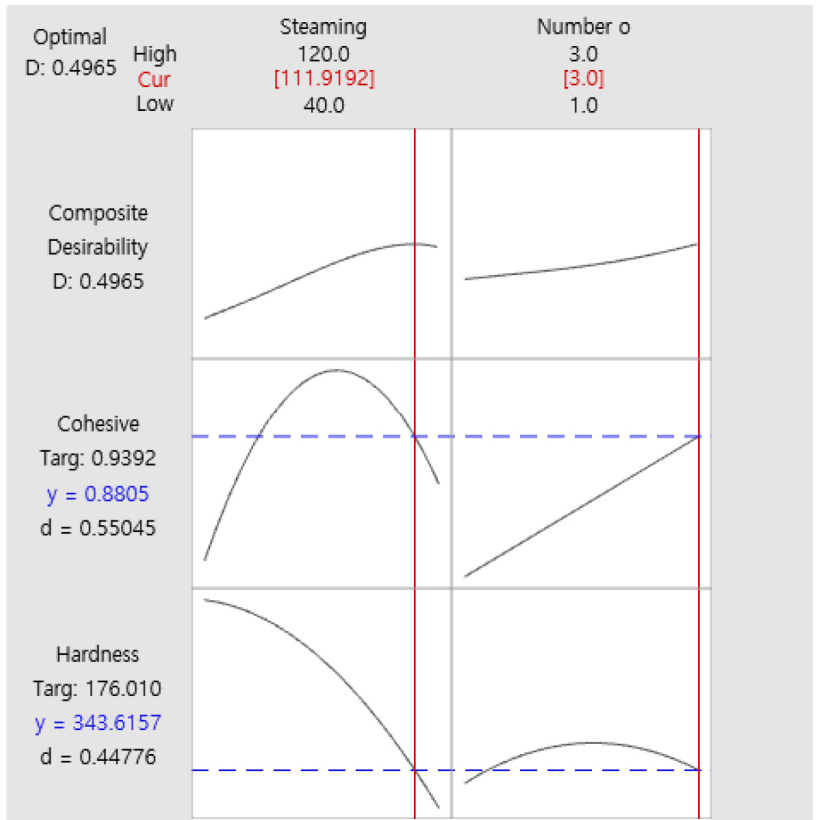

Fig. 9. Optimization of texture properties of rice cake $(Y)$ made with lab scale rice flour according to steaming time $\left(X_{1}\right)$ and number of extrusions $\left(X_{2}\right)$.

고형분:수분 $=1: 0.5$ 의 조건에서 압출 떡을 제조하는 것이 실 험실 규모의 압출 떡 제조 방법으로 가장 바람직한 것으로 사료된다.

\section{관능 특성}

압출 떡에 대해 관능 검사를 진행하였다(Table 9). Cohesiveness의 경우, 압출 조건의 변화에 따른 차이에 대한 유의 미한 식별이 없었으며, 최소 4.2점에서 최대 4.9점의 값을 나 타내었다. 색의 경우, 압출횟수가 증가함에 따라 기호도가 증 가하는 것을 확인하였다. 증자시간 120 분과 압출 1 회를 적용 한 압출 떡이 3 점으로 가장 낮은 값을 나타내었으며, 80 분의 증자시간과 압출 3 회를 적용한 경우가 5.5점으로 가장 높은 선호도를 나타내었다. Hardness의 경우, 증자시간이 증가할 수록, 즉 기기적인 측정에 의한 hardness값이 낮을수록, 기호 도가 유의적으로 증가하는 것을 확인하였으며, 2 시간 동안 증 자를 진행한 압출 떡 견본이 4.7-4.9점으로 가장 높은 선호도 를, 20 분간 증자를 진행한 견본이 1.9-2.3점으로 가장 낮은 선호도를 나타내는 것을 확인하였으며, 압출횟수에 의한 유 의적인 차이는 확인할 수 없었다. 이는 평가를 진행한 패널들 이 익숙한 시중 떡 제품의 경도를 선호하여 가장 유사한 경도 값을 나타낸 견본에 높은 점수를 부여한 것으로 사료된다. Moistness에 대한 기호도는 증자시간에 따라 유의적인 변화 를 나타냈으며, 20분을 증자한 샘플에서 2.4-2.6점으로 가장 낮은 선호도를 나타낸 반면, 40 분과 80 분의 증자시간을 적용 한 샘플에서 4.5-4.8점으로 가장 높은 선호도를 나타내었다. 실험 결과에서 가장 높은 수분 함량을 가진 2시간을 증자한 압출 떡 시료의 moistness 선호도가 가장 높은 게 아닌 점을

Table 9. Sensory evaluation of rice cake with different extrusion conditions

\begin{tabular}{|c|c|c|c|c|c|c|}
\hline \multicolumn{2}{|c|}{ Condition } & \multirow[b]{2}{*}{ Cohesiveness } & \multirow[b]{2}{*}{ Color } & \multirow[b]{2}{*}{ Hardness } & \multirow[b]{2}{*}{ Moistness } & \multirow[b]{2}{*}{ Overall acceptability } \\
\hline $\begin{array}{l}\text { Steaming time } \\
\quad(\min )\left(X_{1}\right)\end{array}$ & $\begin{array}{c}\text { Number of } \\
\text { extrusion }\left(X_{2}\right)\end{array}$ & & & & & \\
\hline \multirow{3}{*}{20} & 1 & $4.5 \pm 0.70^{\mathrm{a}}$ & $3.7 \pm 0.94^{\mathrm{abc}}$ & $2.3 \pm 0.67^{\mathrm{ab}}$ & $2.6 \pm 0.96^{\mathrm{ab}}$ & $1.8 \pm 0.63^{\mathrm{a}}$ \\
\hline & 2 & $4.3 \pm 0.48^{\mathrm{a}}$ & $4.2 \pm 0.78^{\mathrm{bcd}}$ & $1.9 \pm 0.56^{\mathrm{a}}$ & $2.4 \pm 0.69^{\mathrm{a}}$ & $2.6 \pm 0.84^{\mathrm{bc}}$ \\
\hline & 3 & $4.2 \pm 0.63^{\mathrm{a}}$ & $4.4 \pm 0.69^{\text {cde }}$ & $2.0 \pm 1.05^{\mathrm{a}}$ & $2.6 \pm 0.84^{\mathrm{ab}}$ & $2.5 \pm 0.70^{\mathrm{ab}}$ \\
\hline \multirow{3}{*}{40} & 1 & $4.9 \pm 0.87^{\mathrm{a}}$ & $4.7 \pm 1.05^{\text {cde }}$ & $2.5 \pm 0.52^{\mathrm{ab}}$ & $4.6 \pm 0.84^{\mathrm{c}}$ & $3 \pm 0.66^{\mathrm{bc}}$ \\
\hline & 2 & $4.8 \pm 0.78^{\mathrm{a}}$ & $5.2 \pm 1.03^{\mathrm{de}}$ & $2.7 \pm 0.67^{\mathrm{ab}}$ & $4.7 \pm 1.05^{\mathrm{c}}$ & $3.3 \pm 0.94^{\mathrm{bc}}$ \\
\hline & 3 & $4.5 \pm 0.84^{\mathrm{a}}$ & $5.2 \pm 1.22^{\mathrm{de}}$ & $3.0 \pm 0.66^{\mathrm{bc}}$ & $4.7 \pm 0.82^{\mathrm{c}}$ & $3.4 \pm 0.51^{\mathrm{c}}$ \\
\hline \multirow{3}{*}{80} & 1 & $4.4 \pm 0.84^{\mathrm{a}}$ & $3.3 \pm 1.41^{\mathrm{ab}}$ & $3.8 \pm 0.91^{\mathrm{cd}}$ & $4.5 \pm 0.70^{\mathrm{c}}$ & $3.4 \pm 0.69^{\mathrm{c}}$ \\
\hline & 2 & $4.7 \pm 0.82^{\mathrm{a}}$ & $5.3 \pm 1.15^{\mathrm{de}}$ & $4.0 \pm 1.33^{\mathrm{de}}$ & $4.8 \pm 1.03^{\mathrm{c}}$ & $4.7 \pm 0.94^{\mathrm{de}}$ \\
\hline & 3 & $4.9 \pm 0.73^{\mathrm{a}}$ & $5.5 \pm 0.97^{\mathrm{e}}$ & $4.1 \pm 1.19^{\mathrm{de}}$ & $4.8 \pm 0.91^{\mathrm{c}}$ & $4.4 \pm 0.84^{\mathrm{d}}$ \\
\hline \multirow{3}{*}{120} & 1 & $4.6 \pm 0.84^{\mathrm{a}}$ & $3.0 \pm 1.15^{\mathrm{a}}$ & $4.7 \pm 1.15^{\mathrm{de}}$ & $3.4 \pm 0.69^{b}$ & $4.5 \pm 0.84^{\mathrm{d}}$ \\
\hline & 2 & $4.3 \pm 0.82^{\mathrm{a}}$ & $4.6 \pm 1.34^{\text {cde }}$ & $4.9 \pm 1.19^{\mathrm{e}}$ & $3.2 \pm 0.91^{\mathrm{ab}}$ & $5.3 \pm 1.05^{\mathrm{e}}$ \\
\hline & 3 & $4.9 \pm 1.10^{\mathrm{a}}$ & $4.8 \pm 1.13^{\text {cde }}$ & $4.9 \pm 0.99^{\mathrm{e}}$ & $3.4 \pm 0.96^{\mathrm{b}}$ & $5.4 \pm 1.07^{\mathrm{e}}$ \\
\hline
\end{tabular}

${ }^{1)}$ All data are reported as the mean $\pm \mathrm{SE}(\mathrm{n}=10) .{ }^{2}$ Values marked same letter indicates that values were not significantly different among the extrusion conditions $(\mathrm{p}>0.05)$. 
통해 수분 함량이 높다고 하여 반드시 선호도가 높은 것은 아닌 것으로 사료된다. Overall acceptability의 경우 증자시 간 120 분을 적용한 떡 시료들에서 4.5-5.4점으로 가장 높은 선호도를 나타냈으며, 20분동안 증자한 시료들에서 2.4-2.6 점으로 가장 낮은 선호도를 나타내었다. 이는 패널들이 hardness를 가장 중요시하며 평가의 기준으로 채택하였기 때 문으로 사료된다. 추가적으로 동일한 증자시간을 적용한 떡 견본들은 1 회 압출 시 가장 낮은 선호도를 나타냈다.

\section{요 약}

반응표면분석법에 의해 품질인자에 영향을 줄 것으로 판 단되는 고형분:수분 비율, 입자 크기가 다른 미분, 증자시간, 압출횟수와 같은 다양한 압출 조건을 적용한 떡을 압출하여 색차 측정, 조직감 측정, 모델 방정식 도출, 관능검사 등을 실 시하여 최적 조건을 설정하였다. 색차는 압출횟수가 증가함 에 의해 유의적으로 감소하는 것을 확인하였으나, 증자시간, 수분 함량 및 입자 크기에 의한 유의적인 효과는 확인할 수 없었으며, 증자를 40 분 진행한 후 3 회 압출 진행한 압출 떡에 서 0.48 로 가장 낮은 $\Delta \mathrm{E}$ 를 나타내었다. 모델 방정식 중 $\mathrm{R}^{2}$ 값 이 0.7 이상이며, p-value가 0.05 이하인 조직감 항목들을 기 준으로 최적화를 진행하였을 때 종합만족도가 가장 높은 값 을 나타내어 떡볶이 떡 제품과 가장 유사한 조직감을 가지는 압출 조건은 건식 미분을 사용하여 고형분:수분 $=1: 0.5$ 의 조 건에서 약 115 분 증자시간과 압출 1 회 적용한 압출 떡으로 확인되었다. 관능검사에 의해서는 색도와 경도에 의해 만족 감에 대한 유의적인 차이를 나타내었으며, 120 분을 증자한 후 3회 압출한 샘플에서 가장 높은 만족도를 나타내었다. 압 출횟수의 증가에 의해 cohesiveness를 제외한 조직감에 유의 적인 영향이 없으며, 색도 또한 구매를 결정짓는 요소임을 고 려하여 본 연구에서는 115 분 증자 후 3 회 압출을 적용하는 것이 최적의 실험실 단위 압출 떡 제조 조건으로 결정하였다.

\section{감사의 글}

본 결과물은 농림축산식품부의 재원으로 농림식품기술기 획평가원의 농축산물 안전생산 - 유통관리기술개발사업의 지 원을 받아 연구되었음(318079-02).

\section{Conflict of interests}

The authors declare no potential conflict of interest.

\section{ORCID}

Hyng Joo Kim https://orcid.org/0000-0002-6640-162X
Won Byong Yoon https://orcid.org/0000-0002-0370-8317

\section{References}

AOAC. Official Methods of Analysis. 15th ed, Association of Official Analytical Chemists, Washington DC, USA (1996)

aTFIS (aT Food linformation Statistics System). Sales on Each Food of POS Retail. https://www.atfis.or.kr/sales/M0020 20000/search.do?searchItem=CD00000562\&searchDivisi on $=$ CD00000601\&searchCompany $=2 \&$ searchYear $=2018$ $\&$ searchQuarter $=\mathrm{T} \& \mathrm{x}=123 \& \mathrm{y}=14 \&$ selectAccessHistoryI $\mathrm{dx}=0$ (2019) (accessed February 2020)

Bae JS, Yoo CH, Lee KE. Effects of extrusion frequency on the quality characteristics of Ddukgukdduk. Korean J Food Cook Sci, 32, 449-457 (2016)

Chen AH, Larkin JW, Clark CJ, Irwin WE. Textural analysis of cheese. J Dairy Sci, 62, 901-907 (1979)

Choi BK, Kum JS, Lee HY, Park JD. Quality characteristics of rice cake (Backsulki) according to millling type and particle size. Korean J Food Preserv, 12, 230-234 (2005)

Djantou EB, Mbofung CM, Scher J, Desobry S. A modelling approach to determine the effect of pretreatment on the grinding ability of dried mangoes for powder production (Mangifera indica var Kent). J Food Eng, 80, 668-677 (2007)

Heo HY, Joo NM, Han YS. Optimization of jelly with addition of green tea powder using a response surface methodology. Korean J Food Cook Sci, 20, 112-118 (2004)

Jo YJ, Yoon HH. A Study on the quality characteristics of Makpyeon prepared with dry milled rice powder. J Korean Soc Food Cult, 31, 235-242 (2016)

Jung HB, Yu CR, Park HW, Yoon WB. Effect of acid soaking and thermal sterilization on the shape and quality characteristics of Tteokbokki rice cake. Korean J Food Nutr, 31, 737-750 (2018)

Jung KH, Lee SK. Development of a multiple response surface method considering bias and variance of desirability functions. J Korean Inst Ind Eng, 38, 25-30 (2012)

Jung KI, Bang HJ, Boo HJ, Choi YJ. Quality characteristics of Topokkidduk added with Enteromorpha intestinalis powder. J Life Sci, 29, 588-595 (2019) 
Kang HJ, Kum JS, Jeong JH, Lim JK. Effect of number of extrusions on Topokkidduk quality. J Korean Soc Food Sci Nutr, 40, 1612-1616 (2011)

Kang HJ, Park JD, Lee HY, Kum JS. Quality characteristics of Topokkidduk added with soybean flour. Korean J Food Preserv, 19, 688-695 (2012a)

Kang HJ, Lee JK, Lim JK. Quality characteristics of Topokki Garaedduk with different moisture ratios. J Korean Soc Food Sci Nutr, 41, 561-565 (2012b)

Kang HJ, Park JD, Lee HY, Kum JS. Effect of grapefruit seed extracts and acid regulation agents on the qualities of Topokkidduk. J Korean Soc Food Sci Nutr, 42, 948-956 (2013)

Kim JS, Kim SB, Kim TY. Noodle making characteristics of goami rice composite flours. Korean J Community Living Sci, 17, 61-68 (2006)

KOSIS (Korean Statistical Information Service). Annual grain consumption per person. http://kosis.kr/statHtml/statHtml. do?orgId=101\&tblId=DT_1ED0001\&vw_cd=\&list_id $=\&$ scrId $=\&$ seqNo $=\&$ lang_mode $=$ ko\&obj_var_id $=\& i t m \_i d=$ \&conn_path=E1 (2019) (accessed February 2020)

Kum JS. Blooming of rice processing industry. Food Industry and Nutrition, 13, 9-14 (2008)

Lee HJ. Scientific consideration and industrialization of traditional rice cakes. Korean J Food Cookery Sci, 15, 295-308 (1999)

Lee JK, Jeong JH, Lim JK. Quality characteristics of Topokki Garaedduk added with ginseng powder. J Korean Soc Food Sci Nutr, 40, 426-434 (2011)

Lee MG, Son SH, Choung MG, Kim ST, Ko JM, Han WY, Yoon WB. Effect of milling methods and particle size on rice cake (Baeksulgi) characteristics. Food Eng Prog, 19, 1-7 (2015)

Lee SB. Example-Based Experiment Planning Method (using MINITAB). Eretec Inc, Gunpo, Korea (2008)

Lee SB, Kang HJ, Park MS. Chromaticity analysis of natural dyes extracted from sappan wood, gardenia, and mugwort. Appl Chem Eng, 27, 325-329 (2016)

MFDS (Ministry of Food and Drug Safety). Korean Food Code. http://www.foodsafetykorea.go.kr/portal/safefoodlife /food/ foodRvlv/foodRvlv.do (accessed February 2020)

Park JD, Jeon HM, Kum JS, Lee HY. Soaking and drying characteristics of grains and legumes. Korean J Food Preserv, 13, 344-350 (2006)

Park SJ, Moon SW, Lee J, Kim EJ, Kang BS. Optimization of roasting conditions for coffee beans by response surface methodology. Korean J Food Preserv, 18, 178183 (2011)

Park SR, Kim KM, Kim HS, Ra HN, Han GJ. Quality characteristics of Jeung-pyun using dry-milled rice flour prepared from different varieties with different particle sizes. J Korean Soc Food Cult, 33, 588-596 (2018)

Sim CH. Application of response surface methodology for the optimization of process in food technology. Food Eng Prog, 15, 97-115 (2011)

Yoon HJ, Ham IT, Kim JS, Choi JD. Optimization of the manufacturing process for boiled-dried anchovy using response surface methodology (RSM). J Kor Soc Fish Mar Edu, 29, 1984-1993 (2017)

Yu JH, Han GH. Quality charactistics of rice cake (Karedduk) with difference soaking and steaming time. Korean J Food Cook Sci, 20, 630-636 (2004) 